\title{
Challenging claims in the study of migratory birds and climate change
}

Endre Knudsen ${ }^{1}$, Andreas Lindén ${ }^{2 \dagger}$, Christiaan Both ${ }^{3}$, Niclas Jonzén ${ }^{4}$, Francisco Pulido $^{5}$, Nicola Saino ${ }^{6}$, William J. Sutherland ${ }^{7}$, Lars A. Bach ${ }^{8, \S}$, Timothy Coppack ${ }^{9, \ddagger}$, Torbjørn Ergon ${ }^{1, \#}$, Phillip Gienapp ${ }^{10}$, Jennifer A. Gill ${ }^{11}$, Oscar Gordo ${ }^{5}$, Anders Hedenström $^{4}$, Esa Lehikoinen ${ }^{12}$, Peter P. Marra ${ }^{13}$, Anders P. Møller ${ }^{14}$, Anna L. K. Nilsson ${ }^{1}$, Guillaume Péron ${ }^{15}$, Esa Ranta ${ }^{2, ¥}$, Diego Rubolini ${ }^{6}$, Tim H. Sparks ${ }^{16}$, Fernando Spina ${ }^{17}$, Colin E. Studds ${ }^{13}$, Stein A. Sæther ${ }^{1}$, Piotr Tryjanowski ${ }^{16}$ and Nils Chr. Stenseth ${ }^{1, *}$

${ }^{1}$ Centre for Ecological and Evolutionary Synthesis (CEES), Department of Biology, University of Oslo, P.O. Box 1066 Blindern, NO-0316 Oslo, Norway

${ }^{2}$ Integrative Ecology Unit, Department of Biological and Environmental Sciences, P.O. Box 65, 00014 University of Helsinki, Helsinki, Finland

${ }^{3}$ Animal Ecology Group, Centre for Ecological and Evolutionary Studies, University of Groningen, P.O. Box 14, 9750 AA Haren, The Netherlands

${ }^{4}$ Department of Biology, Ecology Building, Lund University, SE-22362 Lund, Sweden

${ }^{5}$ Department of Zoology and Physical Anthropology, Faculty of Biology, Complutense University of Madrid, 28040 Madrid, Spain

${ }^{6}$ Dipartimento di Biologia, Università degli Studi di Milano, via Celoria 26, 20133 Milano, Italy

${ }^{7}$ Conservation Science Group, Department of Zoology, University of Cambridge, Downing Street, Cambridge, CB2 3EJ, United Kingdom

${ }^{8}$ Department of Theoretical Ecology, Ecology Building, Lund University, SE-22362 Lund, Sweden

${ }^{9}$ Zoological Museum, University of Zurich, Zurich, Winterthurerstrasse 190, 8057 Zurich, Switzerland

${ }^{10}$ Ecological Genetics Research Unit, Department of Biological and Environmental Sciences, P.O. Box 65, 00014 University of Helsinki, Helsinki, Finland

${ }^{11}$ School of Biological Sciences, University of East Anglia, Norwich, NR4 7T7, United Kingdom

12 Section of Ecology, University of Turku, 20014 Turku, Finland

${ }^{13}$ Smithsonian Migratory Bird Center, National Zoological Park, P.O. Box 37012 MRC 5503, Washington, DC 20008, United States of America

${ }^{14}$ Laboratoire d'Ecologie, Systématique et Evolution, Université Paris-Sud, Bâtiment 362, 91405 Orsay Cedex, France

${ }^{15}$ Equipe Biométrie et Biologie des Populations, Centre d'Ecologie Fonctionnelle et Evolutive, CNRS UMR 5175, 1919 Route de Mende, 34293

Montpellier, France

${ }^{16}$ Institute of Zoology, Poznan University of Life Sciences, Wojska Polskiego 71C, 60-625 Poznan, Poland

${ }^{17}$ Istituto Superiore per la Protezione e la Ricerca Ambientale, ex-INFS, via Ca' Fornacetta 9, 40064 Ozzano dell'Emilia, Italy

\section{ABSTRACT}

Recent shifts in phenology in response to climate change are well established but often poorly understood. Many animals integrate climate change across a spatially and temporally dispersed annual life cycle, and effects are modulated

*Address for correspondence (Tel: +47 228544 00; Fax: +47 228540 01; E-mail: n.c.stenseth@bio.uio.no).

${ }^{\dagger}$ Present address: Centre for Ecological and Evolutionary Synthesis (CEES), Department of Biology, University of Oslo, P.O.Box 1066 Blindern, NO-0316 Oslo, Norway

$\S$ Present address: Ecoinformatics and Biodiversity Group, Department of Biological Sciences, Aarhus University, Ny Munkegade 114, DK-8000 Aarhus C, Denmark

${ }^{\ddagger}$ Present address: Institute of Applied Ecology (IfAÖ GmbH), Department of Ornithology, Alte Dorfstrasse 11, 18184 Neu Broderstorf, Germany

\# Present address: Program for Integrative Biology, Department of Biology, University of Oslo, P.O.Box 1066 Blindern, NO-0316 Oslo, Norway

${ }^{¥}$ Deceased during the preparation of this manuscript. 
by ecological interactions, evolutionary change and endogenous control mechanisms. Here we assess and discuss key statements emerging from the rapidly developing study of changing spring phenology in migratory birds. These well-studied organisms have been instrumental for understanding climate-change effects, but research is developing rapidly and there is a need to attack the big issues rather than risking affirmative science. Although we agree poorly on the support for most claims, agreement regarding the knowledge basis enables consensus regarding broad patterns and likely causes. Empirical data needed for disentangling mechanisms are still scarce, and consequences at a population level and on community composition remain unclear. With increasing knowledge, the overall support ('consensus view') for a claim increased and between-researcher variability in support ('expert opinions') decreased, indicating the importance of assessing and communicating the knowledge basis. A proper integration across biological disciplines seems essential for the field's transition from affirming patterns to understanding mechanisms and making robust predictions regarding future consequences of shifting phenologies.

Key words: bird migration, climate change, phenology, annual life cycle, match-mismatch, endogenous control, phenotypic plasticity, microevolutionary change, population trends, integrative biology.

\section{CONTENTS}

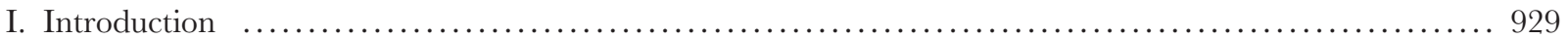

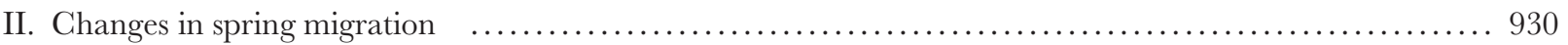

(1) Claim 1: birds advance their spring migration in response to climate change $\ldots \ldots \ldots \ldots \ldots \ldots \ldots . \ldots 930$

(2) Claim 2: phenological response to climate change depends on migratory distance $\ldots \ldots \ldots \ldots \ldots \ldots . \ldots 931$

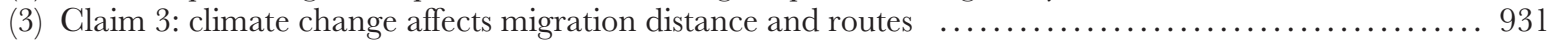

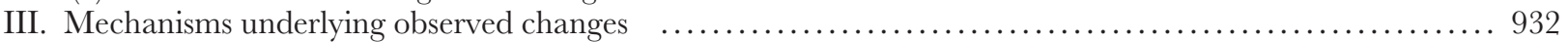

(1) Claim 4: mechanisms controlling the timing of migration are generally hardwired $\ldots \ldots \ldots \ldots \ldots \ldots . \ldots 32$

(2) Claim 5: changes in the timing of migration are mainly due to phenotypic plasticity $\ldots \ldots \ldots \ldots \ldots . \ldots 93$

(3) Claim 6: phenotypic variation in timing of arrival is mainly due to weather conditions en route $\ldots . . . .933$

(4) Claim 7: responses to climate change are constrained by the annual cycle $\ldots \ldots \ldots \ldots \ldots \ldots \ldots \ldots \ldots \ldots \ldots$

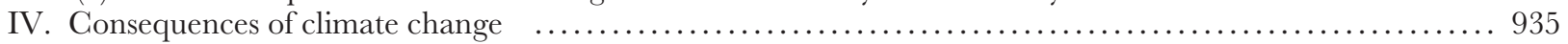

(1) Claim 8: migratory birds suffer from increased trophic mismatch on the breeding grounds $\ldots \ldots \ldots . .935$

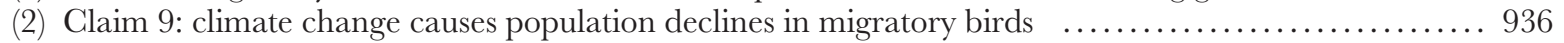

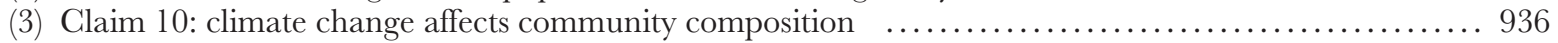

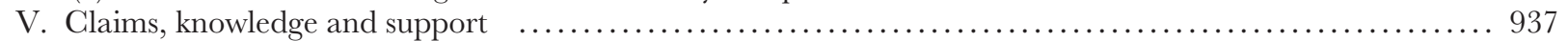

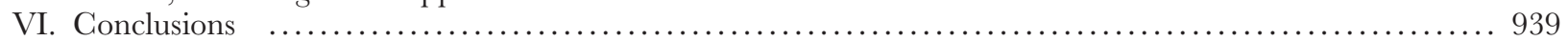

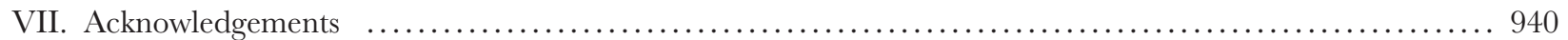

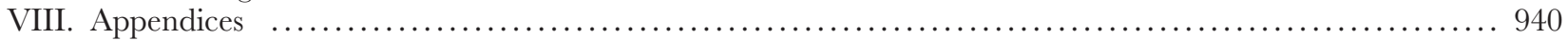

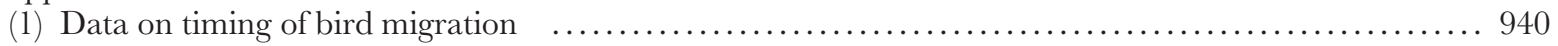

(2) Perspectives: searching for generality in the phenology of migratory birds $\ldots \ldots \ldots \ldots \ldots \ldots \ldots \ldots . \ldots 41$

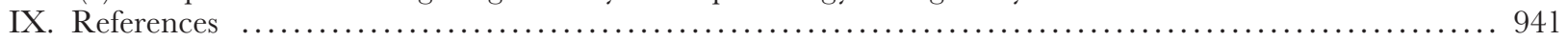

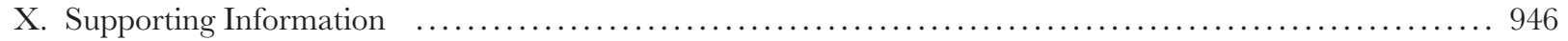

\section{INTRODUCTION}

Recent climate change has shifted patterns of abiotic factors playing key roles in structuring species abundance and geographical dispersion, and their variability over time (Gitay et al., 2002; Stenseth et al., 2002; Walther et al., 2002; IPCG, 2007). A failure of species to respond sufficiently to the new environmental conditions may result in population declines or even species extinctions (Thomas et al., 2004; Parmesan, 2006). The timing of life-history events with respect to a fluctuating environment can be crucial for survival and successful reproduction, and classical life-history theory predicts that individuals should optimize the match in space and time with important resources (Lack, 1968; Roff, 2002). Hence, it is not surprising that shifts in the seasonal timing of life-history events (i.e. phenology) are among the most well-established effects of climate change (Parmesan \& Yohe, 2003; Rosenzweig et al., 2008). It is, however, the combined effects of spatial changes in species distributions and changes in timing, relative to those of interacting species, that will determine the viability of populations in light of climate change and other human impacts, such as habitat and landscape changes. There is so far no general understanding of how phenological impacts of climate change integrate over the course of a seasonal life cycle, and how this translates to individual life histories and population fluctuations. Furthermore, transitional phases in the life histories of animals may involve movements between distant areas, making it hard to pinpoint phenological events and climatic influences in time and space.

Here we focus on migratory birds, which have fascinated humans since ancient times and nourished a vigorous 
research field over several centuries (Berthold, 2001). Bird migration has presumably evolved repeatedly as a response to seasonality in environmental conditions, resulting in a lifestyle where the spatial and temporal schedule of events over the annual cycle represents an overall optimal match with the environment (Newton, 2008). There is a long tradition for using birds as model organisms for studying impacts of climate on animals, and changes in the timing of migration and breeding in birds are indeed among the best documented responses to climate change (Parmesan \& Yohe, 2003; Møller, Fiedler \& Berthold, 2004b; Rubolini et al., 2007b). We see this as a good area for seeking in-depth understanding of phenological changes.

In this rapidly developing, but still fragmented field of research, a number of claims and assumptions have been made, not all of which may be as well justified as we believe. In order to improve our understanding of the total picture and avoid the pitfalls of affirmative science, we review and critically synthesize this literature. We focus particularly on issues pertaining to timing of spring migration - i.e. the transition from the non-breeding period via migration to the arrival on breeding grounds. Climate-change effects are most consistent and well studied for this phase, and fitness effects are highly likely through the close association with onset of reproduction. We here list what we consider the more important key statements, discuss their basis and subjectively score their support and how much has been done to check their validity. We identify gaps in knowledge and make suggestions on how to proceed in order to improve our scientific knowledge and predictive power regarding these issues.

\section{GHANGES IN SPRING MIGRATION}

\section{(1) Glaim 1: birds advance their spring migration in response to climate change}

Recent decades have seen a wealth of studies on long-term trends in timing of spring migration and arrival at breeding grounds in relation to changing climate. Extensive reviews show a general pattern of advancement (Lehikoinen, Sparks \& Zalakevicius, 2004; Gordo, 2007; Rubolini et al., 2007b; Lehikoinen \& Sparks, 2010), irrespective of the specific metric considered (Appendix 1). However, estimated rates of advancement vary according to a number of factors, including species or taxonomic group, life-history traits and geographic region (Butler, 2003; Lehikoinen et al., 2004; Gordo, 2007; Rubolini et al., 2007b; Végvári et al., 2009; Lehikoinen \& Sparks, 2010). Also, trends are not constant over time, and non-linear responses to temperature have been suggested (Gordo \& Sanz, 2006; Askeyev, Sparks \& Askeyev, 2009). Most studies do not consider different responses between sexes or age groups (see online supporting information, Appendix S1).

Within species or populations, advancement is typically most pronounced early in the season (Lehikoinen et al.,
2004; Jonzén et al., 2006; Lehikoinen \& Sparks, 2010). Two meta-analyses of a large number of European time series (Lehikoinen et al., 2004; Rubolini et al., 2007b) show a mean advancement of approximately 0.4 days year ${ }^{-1}$ for first arrival dates, compared to $0.1-0.2$ days year $^{-1}$ for mean or median migration dates. This might reflect a larger impact of climate on early migrating individuals (Vähätalo et al., 2004), as well as sampling biases and statistical properties for first arrival dates (Appendix 1), but the general pattern is consistent with studies using more reliable metrics. Even though there is non-negligible variation both among regions and species or populations (Peñuelas, Filella \& Comas, 2002; Lehikoinen et al., 2004; Rubolini et al., 2007b; Lehikoinen \& Sparks, 2010), the patterns of overall advancement emerging from studies of North American and Australian birds are broadly similar to those in Europe (Mills, 2005; MurphyKlassen et al., 2005; Beaumont, McAllan \& Hughes, 2006; Miller-Rushing et al., 2008b).

Three lines of observational evidence link observed changes to changes in climatic conditions. (1) Many studies have shown clear and predictable relationships between bird migration and climate variables, including both local weather variables (see also Claim 6, Section III.3) and climatic indices such as the North Atlantic Oscillation (NAO) index (Stenseth et al., 2003; Lehikoinen et al., 2004; Gordo, 2007; Lehikoinen \& Sparks, 2010). These findings typically persist after accounting for potentially confounding effects of long-term trends (Jonzén et al., 2006, 2007; Rubolini et al., 2007a; Saino et al., 2007), and reversal in temperature trends between cooling and warming periods during the last century is matched by corresponding delays and advances in migration phenology (Lehikoinen et al., 2004). (2) Geographical and between-species patterns of variability in phenological trends support the notion of climate-induced changes. Species differ in their movements and ecology, and climate change is not uniform (Gitay et al., 2002; Stöckli \& Vidale, 2004; IPCC, 2007; Karlsen et al., 2009; Sparks et al., 2009). Hence, we do not expect trends to be equal across species and geographic regions (Ahola et al., 2004; Both, Bijlsma \& Visser, 2005; Hüppop \& Winkel, 2006; Askeyev et al., 2007, 2010; Both $\&$ te Marvelde, 2007). (3) Studies of individually marked populations are able to link variability among individuals and years to climatic conditions experienced in wintering areas or during migration (Saino et al., 2004; Gunnarsson et al., 2006). Good individual-level data on arrival are, however, hard to obtain for most species (Appendix 1), and we are only aware of two studies examining phenotypic plasticity in the timing of passerine migration in the wild, showing that individual barn swallows (Hirundo rustica) advance arrival dates in years with beneficial environmental conditions on the wintering (Saino et al., 2004) or staging (Balbontín et al., 2009) grounds.

In sum, there is strong evidence that migratory birds have advanced their spring migration and arrival during the last decades in a manner consistent with climate change, but there is large and poorly understood variability among species, and mechanisms underlying change need to be elucidated further. It should also be noted that most data are 
from passage areas or close to breeding grounds; we often know very little about departure dates from wintering areas in, for instance, Africa.

\section{(2) Claim 2: phenological response to climate change depends on migratory distance}

Long-distance migrants, particularly those crossing the Sahara desert, are often claimed to show a smaller phenological response to climate change than short-distance migrants (Berthold, 1991; Both \& Visser, 2001; Butler, 2003; Pulido \& Widmer, 2005). This assertion is partly based on the expectation of strong stabilizing selection on the timing of arrival (Claim 8, Section IV.1) having resulted in rigid endogenous control of migration schedules synchronized by, e.g. photoperiod for long-distance migrants (Berthold, 1996; Gwinner, 1996), while the proximity of wintering and breeding areas for short-distance migrants allows adjustment of departure and arrival schedules according to weather conditions at their destination (Claim 6, Section III.3).

Rigid endogenous control could result in reduced flexibility of migration timing in response to climatic factors, i.e. canalization of the phenotype (Pulido \& Widmer, 2005). To the best of our knowledge, explicit comparisons of endogenous control between short- and long-distance migrants have not been performed, although for a few species there is experimental evidence suggesting greater betweenindividual variability in duration and intensity of migratory activity in short-distance migrants (Gwinner, 1968; Berthold et al., 1972). Stronger stabilizing selection on migratory traits of long-distance migrants has been repeatedly advocated, but evidence is indirect (Pulido \& Widmer, 2005), and the strength of selection on arrival dates is very rarely estimated (Møller et al., 2009a). Some studies indicate larger interspecific variability in trends among European shortdistance compared to long-distance migrants (Jonzén et al., 2006; Rubolini et al., 2007b; Rubolini, Saino \& Møller, 2010), but this could also be due to the difference in overall timing, since weather (and hence migration or arrival dates) can be more variable early in spring (Loxton \& Sparks, 1999; Newton, 2008; Wilson, 2009). There is no consistent pattern of short-distance migrants responding more strongly to favourable conditions (i.e. high temperature and NAO values) (Forchhammer, Post \& Stenseth, 2002; Hüppop \& Hüppop, 2003; Hubálek, 2004; Stervander et al., 2005; Jonzén et al., 2006; Gienapp, Leimu \& Merilä, 2007). Moreover, because long-distance migrants encounter a larger spectrum of environmental conditions en route, the comparison between short- and long-distance migrants can be biased, due to issues such as statistical power and possibly opposite effects in different parts of the migration route.

The evidence for differential trends in spring migration phenology according to migration distance is somewhat mixed; while clearly most studies have reported larger advancement in short-distance migrants (Butler, 2003; Lehikoinen et al., 2004; Rubolini et al., 2007b, 2010; MillerRushing et al., 2008b; Lehikoinen \& Sparks, 2010), others did not find any difference (Hüppop \& Hüppop, 2003;
Zalakevicius et al., 2006), or even greater advancement in long-distance migrants (Stervander et al., 2005; Jonzén et al., 2006). Meta-analyses indicate overall larger advances for short-distance migrants in North America (Gienapp et al., 2007), but show inconsistent results for Europe (Gienapp et al., 2007; Rubolini et al., 2007b). Studies also differ in terms of temporal scope and species composition, and environmental constraints on the progress of migration (Both \& te Marvelde, 2007; Gordo, 2007; Newton, 2008). In addition, relevant trends in abiotic and biotic conditions (Menzel, 2000; Stöckli \& Vidale, 2004; Sparks et al., 2009) are likely to be different for short-distance and the later long-distance migrants.

In sum, even though differences are likely to exist, no firm patterns of differential level of response to climate according to migratory distance can be established so far. Case studies and meta-analyses should more properly account for confounding factors and effects of study design.

\section{(3) Claim 3: climate change affects migration distance and routes}

It has frequently been hypothesized that changes in spring arrival dates are due to changes in the timing or speed of migration (Gwinner, 1986; Pulido, 2007a). However, range shifts (Thomas \& Lennon, 1999; Böhning-Gaese \& Lemoine, 2004; Hitch \& Leberg, 2007; La Sorte \& Thompson, 2007; Maclean et al., 2008; Zuckerberg, Woods \& Porter, 2009; Brommer \& Møller, 2010) and some route changes (Sutherland, 1998; Fiedler, 2003; Newton, 2008) are well documented, and may provide additional pathways for adaptive change in phenology (Pulido \& Berthold, 2004; Pulido, 2007a; Coppack et al., 2008; Visser et al., 2009b).

Climate change is likely to affect movement patterns in at least three ways. Firstly, the propensity of individuals to migrate can change over time. Reviews show ample observational evidence (from case studies of diverse bird orders) of migratory birds becoming more sedentary, i.e. wintering closer to their breeding grounds and abandoning the more distant parts of their former wintering range (Sutherland, 1998; Fiedler, 2003; Newton, 2008). Improved feeding conditions, due to mild winters and in some cases possibly additional feeding by humans, is the most likely explanation. Selection for shorter migration distance can result in rapid evolution of residency, as suggested by a common garden experiment with blackcaps (Sylvia atricapilla) (Pulido \& Berthold, 2010).

Secondly, changes in both breeding and wintering ranges are well documented (Sutherland, 1998; Böhning-Gaese \& Lemoine, 2004; Brommer, 2004; Hitch \& Leberg, 2007; La Sorte \& Thompson, 2007; Maclean et al., 2008; Newton, 2008; Zuckerberg et al., 2009). At intermediate and northern latitudes, observed range shifts are mostly (breeding range) or almost always (winter range) northwards or towards areas of initially harsher climate, suggesting they are driven by recent climate amelioration. Although rates of distributional change depend on whether the change is measured at the boundaries or in the interior of a species' geographic distribution, and 
southern range margins of northerly breeding species might not have shifted (Brommer \& Møller, 2010), there are indications that shifts in winter ranges of migratory birds occur at rates at least as high as shifts in summer ranges (Thomas \& Lennon, 1999; Devictor et al., 2008; Maclean et al., 2008). Furthermore, there are more indications of shortening than lengthening of migratory routes (Sutherland, 1998; Fiedler, Bairlein \& Koppen, 2004; Newton, 2008; Visser et al., 2009b). On the other hand, species distribution models coupled with climate-change scenarios suggest a larger and more consistent shift in northern breeding ranges (Huntley et al., 2007; Barbet-Massin et al., 2009; Doswald et al., 2009), while wintering areas in the Southern Hemisphere may become shifted to the south (Barbet-Massin et al., 2009); i.e. to higher latitudes, as in the Northern Hemisphere. Several species known for their trans-Saharan migrations now overwinter in Spain and other parts of southern Europe (examples in Newton, 2008). Geographical barriers may prevent gradual range shifts - for instance, the Sahara desert restricts available wintering areas for Palearctic long-distance migrants (Pulido \& Berthold, 2004; Pulido, 2007a).

Thirdly, migration routes are shaped by biogeographic history and can be less than optimal in terms of complexity and travelled distance (Sutherland, 1998; Newton, 2008; Bensch et al., 2009). For most species of long-distance migrants, there is poor knowledge of the migratory connectivity (i.e., the linkage of populations between wintering, migration and breeding; see online supporting information, Appendix S2). In the absence of severe geographical constraints there could be potential for adaptive change in migration routes. For instance, microevolution of a novel migratory direction towards $\mathrm{W}-\mathrm{NW}$ within a time scale of a few decades was demonstrated for blackcaps breeding in Central Europe and previously wintering along the Western Mediterranean (Berthold et al., 1992).

Phenological consequences of spatial change in migration patterns are so far little studied, but are likely to be important (Pulido, 2007a), not the least in light of range shifts predicted by climate envelope models (Huntley et al., 2007). While a reduction in migratory distance seems likely to result in advancing arrival (Coppack \& Pulido, 2004; Pulido, 2007a), we are not aware of any attempts to model rigorously the implications for migration phenology. This task is likely to be hard, since it is not clear how to separate and model various pathways for phenological change in any particular observed case, and phenological responses are likely to be constrained by seasonal interactions between stages of the annual cycle (Claim 7, Section III.4).

\section{MEGHANISMS UNDERLYING OBSERVED GHANGES}

\section{(1) Glaim 4: mechanisms controlling the timing of migration are generally hardwired}

It has been claimed that the main reason underlying observations of insufficient adjustment of the timing of spring arrival in long-distance migrants to changing phenology on the breeding ground is the control of migration by a rigid endogenous migration programme (Both \& Visser, 2001; Coppack \& Both, 2002).

This argument is based on empirical findings under laboratory conditions, with some support from field studies. For a number of study species, the timing of gonadal growth, moult, fat deposition and migratory activity has been shown to be controlled by the circannual rhythms of an endogenous programme (Gwinner, 1986, 1996; Berthold, 1996), which under controlled laboratory conditions appear largely insensitive to perturbations in environmental factors such as precipitation, temperature, and (to some extent) food availability (Berthold, 1984; Gwinner, 1996). These rhythms are strongly influenced by photoperiod, i.e. day length per se and changes in day length, and recent studies suggest high heritability (Helm \& Visser, 2010) and linkage to geographically distinct annual scheduling (Helm, Schwabl \& Gwinner, 2009). Photoperiod has been suggested to be the most reliable predictive cue used by birds to initiate migration both on the breeding and on the wintering grounds (Kok, Van Ee \& Nel, 1991; Coppack \& Both, 2002; Coppack \& Pulido, 2004). This could be particularly so for long-distance migrants wintering in the tropics, and observations of smaller variation in spring arrival times for these species compared to short-distance migrants (Mason, 1995; Lehikoinen et al., 2004; Jonzén et al., 2006; Rubolini et al., 2007b) could indicate stronger endogenous control (see also Claim 2, Section II.2).

On the other hand, the timing of migration may be constrained by the environment in addition to endogenous mechanisms. Long-term studies on the American redstart (Setophaga ruticilla) show that departure schedules from wintering grounds are affected by habitat occupancy via differences in food abundance, which is linked to rainfall (Marra, Hobson \& Holmes, 1998; Studds \& Marra, 2005, 2007). Migration requires fuel deposition and for some species completion of winter moult, and a poor food supply can delay the rate of both and hence departure dates (Saino et al., 2004; Newton, 2008). Day length varies little near the equator, and intraspecific variation in the phenological response of moult and migration (and for migratory restlessness in non-migratory populations; Helm \& Gwinner, 2006) to photoperiod has been described for many species (Berthold, 1996). In the blackcap, additive genetic variation for this response has been found, though it is unclear how large it is (Coppack, Pulido \& Berthold, 2001). A comparison of the timing of autumn migration for two species under laboratory conditions suggests that small phenotypic variability in long-distance migrants is not due to differences in additive genetic variation, but possibly a result of environmental forcing resulting in similar phenotypes (environmental canalization; Appendix S2, Pulido \& Widmer, 2005).

In some groups of large, long-living birds (cranes, geese, swans and storks), migratory routes and stopover sites are predominantly culturally transmitted in autumn. This has 
been hypothesized to facilitate rapid adaptive changes in wintering areas or migration routes (Sutherland, 1998; van Noordwijk et al., 2006; Newton, 2008). Although these species also likely possess a spatio-temporal programme controlling their annual cycle (Chernetsov, Berthold \& Querner, 2004; Newton, 2008), it can be overridden or modified by environmental input and individual experience. Similarly, in species with a rigid circannual organization (and apparently hard-wired behaviour), field evidence suggests that the endogenous programme strongly determines migratory route and phenology mainly on the first migratory trip from the breeding to the non-breeding area. Thereafter, birds appear to rely more on their experience and on environmental information (Berthold, 2001; Mouritsen, 2003; Pulido, 2007b; Thorup et al., 2007; Chernetsov, Kishkinev \& Mouritsen, 2008).

Hence, although there is strong support for endogenous control of the timing and spatiotemporal progress of bird migration in at least some species, it is unclear how rigid this control is in the wild. A lack of response to climate in migration phenology need not imply a rigid program, but could also be due to constraints pertaining to the annual cycle (Claim 7, Section III.4) or genetic architecture (Appendix S2).

\section{(2) Glaim 5: changes in the timing of migration are mainly due to phenotypic plasticity}

Adaptive adjustment of a population to climatic changes can be a combination of evolutionary change and individual phenotypic adjustment (i.e. phenotypic plasticity, including trans-generational maternal effects). The relative importance of the two processes has been debated and is critical for rates and limits of phenotypic change. In principle, changes due to phenotypic plasticity will be faster, but might be rather limited. Adaptive evolution is likely to be slower, but can in theory continue until additive genetic variation is depleted (Pulido \& Berthold, 2004).

In general, it has been assumed that phenotypic plasticity is sufficient for explaining the observed changes in spring arrival. A number of empirical results suggest the importance of phenotypic plasticity: (1) in barn swallows, population variability in arrival dates is partly a consequence of individual responses to environmental conditions in winter quarters (Saino et al., 2004) and en route (Balbontín et al., 2009). (2) Established correlations between weather en route and at arrival (Claim 6, Section III.3) also are supported for populations of intensively studied species (Ahola et al., 2004; Both et al., 2005; Hüppop \& Winkel, 2006; Both \& te Marvelde, 2007). (3) Meta-analyses of rates of phenotypic change in response to climate change suggest phenotypic plasticity rather than adaptive evolution (Gienapp et al., 2007, 2008; Hendry, Farrugia \& Kinnison, 2008), and changes in the timing of breeding seem to be due to phenotypic plasticity (Pulido \& Berthold, 2004; Charmantier et al., 2008). (4) Laboratory studies indicate plasticity in timing related to photoperiodic cues. Several long-distance migrants showed earlier onset of migratory activity when subjected to photoperiods of more northern areas, suggesting that a change in wintering latitude could induce profound changes in the annual schedule (Coppack \& Pulido, 2004; Coppack et al., 2008).

However, this does not exclude the possibility of evolutionary change (Pulido \& Berthold, 2004; Gienapp et al., 2007; Pulido, 2007b), and it has been claimed that observed changes in spring arrival may reflect an evolutionary response to changing environmental conditions (Jonzén et al., 2006, 2007). Various studies show that rapid evolutionary change is possible and expected (Brown \& Brown, 2000; Pulido \& Berthold, 2004, 2010; Møller, 2007b; Pulido, 2007a). In order properly to demonstrate adaptive evolutionary responses to climate we need to show that (1) there is phenotypic variation, (2) this variation is inherited, (3) fitness is largely determined by phenotypic variation, and (4) this variation in fitness is caused by changes in meteorological variables (Gienapp et al., 2008). Phenotypic variation in migratory traits is evident from field studies, but these primarily concern variation in arrival or migration (not departure) dates among sexand age-classes, populations and species. In order to assess the relative influence of genetic and environmental effects on phenotypic variation, we need information on betweenand within-individual variability, which still is scarce (van Noordwijk etal., 2006; Pulido, 2007b). Heritability of migratory traits has been established (Pulido \& Berthold, 2003; Pulido, 2007b), but only for few populations and species, and mostly in laboratory experiments. Hence, it remains unclear how important genetic variation is in the expression of phenotypic variation of migratory traits in the wild. Selection pressures in terms of consequences of arrival date for survival, mating opportunities, access to food and territories are well identified (Claim 8, Section IV.1; Kokko, 1999), but there is a lack of empirical data on actual consequences of climate change. Selection on the timing of migration has been demonstrated in the wild (Brown \& Brown, 2000; Møller, 2007b), but we are only aware of one study (Møller, 2007b) linking selection on arrival time with climatic variables, and trying to separate between fitness effects of the timing of arrival and the timing of breeding.

In sum, empirical support has so far favoured phenotypic plasticity as the main mechanism underlying recent changes in the timing of migration. However, adaptive responses to selection pressures are also expected and observed, though evolutionary change is hard to demonstrate. More needs to be done to evaluate the relative importance of both processes.

\section{(3) Claim 6: phenotypic variation in timing of arrival is mainly due to weather conditions en route}

The effect of weather conditions experienced during migration on trends and between-year variability in arrival dates is important to assess, since it sheds light on the potential for migratory birds to cope with climate change by individual plasticity or evolutionary change in the timing of migration (Pulido, 2007a). For instance, the advancing spring arrival of the song thrush (Turdus philomelos) to the southeast Baltic over the past 40 years was mainly explained by increasing 
tailwind frequency and temperatures en route (Sinelschikova et al., 2007).

Apart from the recent focus on correlations between arrival date and local weather (Claim 1, Section II.1), it is well known from the literature that weather variables affect observable migration intensity (Richardson, 1978; Berthold, 1996; Newton, 2008), as well as flight speed and stopover decisions during migration (Hedenström \& Alerstam, 1995; Hedenström, 2008). Many species apparently respond rather similarly and possibly in a simple threshold manner, to a limited number of weather variables governing departure and flight conditions - such as wind, precipitation, temperature, and visibility of celestial cues (Ákesson et al., 2001; Erni et al., 2002; Cochran et al., 2005; Newton, 2008).

The question of whether the cumulative effect of weather en route is sufficient to explain the observed changes in migration timing needs to be considered in light of variability in temporal trends along the migratory route, and speciesand individual-specific migration strategies and constraints. Increasing temperatures at intermediate and high latitudes are expected to improve conditions for migration and increase food availability (hence potentially decrease stopover durations) due to advancing phenologies of vegetation and food resources (Gordo, 2007), while effects of climate change in the tropics are less clear (Hulme et al., 2001; Herrmann, Anyamba \& Tucker, 2005; Bell, 2007; Robson \& Barriocanal, 2010). Due to spatially correlated weather and the general lack of knowledge of wintering areas and pre-migratory movements in most species (Newton, 2008), it is hard to separate the effects of earlier departure (Marra et al., 1998; Gordo et al., 2005; Jonzén et al., 2006; Saino et al., 2007; Studds \& Marra, 2007; Gordo \& Sanz, 2008) and increased migration speed (Marra et al., 2005). The role of spatiotemporal correlation patterns of environmental variables along the flyway has only recently been studied in detail (Marra et al., 2005; van der Graaf et al., 2006; Saino \& Ambrosini, 2008), and might explain differential trends in timing along different flyways (Tøttrup et al., 2008). Recent case studies suggest the importance of fine-tuning the progress of migration in response to the environment en route (Saino \& Ambrosini, 2008; Tøttrup et al., 2010), and such effects could mask phenotypic plasticity in the onset of migration (Both, 2010).

Adjustment of migratory movements based on short-range meteorological correlations has frequently been advocated for short-distance migrants (Hötker, 2002; Newton, 2008), while it has been argued that long-distance migrants have no available cues for predicting conditions at the breeding grounds when they are in the wintering area or at distant staging sites (Cotton, 2003; Lehikoinen et al., 2004; Gordo et al., 2005). However, due to global atmospheric circulation patterns such as those underlying the NAO (Appendix S2), meteorological conditions in breeding areas of Northern Europe and those in the central and eastern Mediterranean correlate negatively, implying close to zero correlation (and hence poor opportunity to predict weather conditions at destination) at intermediate latitudes (Saino \& Ambrosini,
2008). Moreover, temperature anomalies in the Sahel (a major wintering/stop-over region for long-distance migrants (Newton, 2008) just before the start of spring migration are correlated with those in Europe in the following two months (Saino \& Ambrosini, 2008). Hence, migrants might be able to tune both the onset and progression of migration based on en route prediction of meteorological conditions ahead. This calls for further consideration of the spatiotemporal organization of migratory journeys and integration with optimal migration theory (see online supporting information, Appendix S3).

It is beyond doubt that the timing of arrival can be affected by weather conditions en route, but data are still insufficient to evaluate properly the relative magnitude of this effect for individuals, except for a few special cases (see, e.g. Shamoun-Baranes et al., 2003; Thorup et al., 2006; Strandberg \& Alerstam, 2007). More research is also needed to separate between various direct (e.g. tailwinds) and indirect (e.g. enhanced food availability) effects of local weather en route, and to assess effects of migratory strategy and distance (Claim 2, Section II.2).

\section{(4) Glaim 7: responses to climate change are constrained by the annual cycle}

Since the link between winter habitat conditions and timing of arrival to breeding grounds was made explicit at the level of individuals using colour marking and stable isotopes (Marra et al., 1998; Gill et al., 2001; Gunnarsson et al., 2005), there has been increasing awareness of constraints imposed by the annual cycle on migration and arrival phenology (Carey, 2009). Particular interest has been directed at long-distance migrants, whose annual schedule incorporates very different environments, and who are especially time-constrained due to prolonged migration periods, also requiring fuel deposition on top of the usual requirements for breeding and moulting (Hedenström, 2006, 2008).

Constraints imposed by the annual cycle can partly be understood in terms of interactions between the wintering, migration and breeding stages (seasonal interactions; Appendix S2). Effects of factors in one stage can cascade to the next stage, i.e. carry-over effects (Marra et al., 1998; Runge \& Marra, 2005; Pulido, 2007a; Newton, 2008; Møller, Flensted-Jensen \& Mardal, 2009b). More generally, since migratory birds use different areas at different stages of their annual cycle, and climate change varies across space and time, they might not be able to adapt to all important environmental changes encountered. This can have a genetic component, reflecting the inability of populations to evolve particular trait combinations due to the lack of sufficient genetic variation in a multi-trait character space and/or due to unfavourable genetic correlations (Appendix S2). Also, constraints can be due to the inability to change a trait if particular ecological conditions at the preceding stages are not met, or if the change induces a penalty at a later stage. If, for instance, conditions on the breeding grounds favour earlier arrival, but conditions at the wintering sites or along the migratory route have not changed, birds may not be able to advance their arrival since they will not find the food 
needed to build up energy reserves required for migrating earlier or faster (Strode, 2003; Hüppop \& Winkel, 2006; Both \& te Marvelde, 2007). On the other hand, if there is environmentally induced change in one life-cycle stage but not in later stages, a mismatch between environmental conditions (e.g. food availability; Claim 8, Section IV.1) and the life cycle can arise. As an example, pied flycatchers (Ficedula hypoleuca) breeding in Finland are arriving earlier on the breeding grounds, due to improved conditions during migration, but do not breed earlier since conditions on the breeding grounds have not advanced - hence experiencing less favourable conditions upon arrival and a prolonged pre-breeding period (Ahola et al., 2004). Changes in arrival on the breeding grounds could be constrained by a range of abiotic factors during migration (Claim 6, Section III.3) or wintering (Marra et al., 1998; Saino et al., 2004; Norris, 2005; Studds \& Marra, 2007), and may also be determined by shifting winter ranges (Coppack \& Pulido, 2004; Pulido, $2007 a$; Claim 3, Section II.3).

Apart from constraints pertaining to post-breeding moult, the issue of flexibility in scheduling of the annual cycle has received little attention. In general, flexibility in timing is expected to relate inversely to migratory distance and body size (Hedenström, 2006, 2008), as well as to the number and spacing of stages and substages in the annual cycle (Wingfield, 2008). Climate change may affect the latter, for instance by earlier arrival allowing extra clutches or more time between clutches (Møller, 2007a; Najmanová \& Adamík, 2009; Møller et al., 2010a). On the other hand, ontogenetic effects on the timing of migration are also little explored. An effect of hatching date on the timing of subsequent spring migration has been suggested for pied flycatchers (Both, 2010), and spring arrival of Arctic terns (Sterna paradisea) correlated positively with breeding date the previous year (Møller et al., 2009b). For birds migrating long distances non-stop, the link between breeding latitude and departure dates from wintering quarters, as well as subsequent return migration, can be remarkably strong (Conklin et al., 2010).

Overall, potential constraints on phenological responses due to the interaction of events across periods of the annual cycle, in particular carry-over effects, are well identified, but there is little empirical knowledge about their consequences for responses to climate change. Further progress also needs to be made regarding ways to integrate such constraints in modelling efforts (Appendix S3).

\section{GONSEQUENGES OF GLIMATE GHANGE}

\section{(1) Claim 8: migratory birds suffer from increased trophic mismatch on the breeding grounds}

A mere change in the timing of migration does not necessarily mean a proper response in context of the birds' breeding environment (Visser \& Both, 2005; Goodenough, Hart \& Stafford, 2010; Saino et al., 2010). If timing of arrival to breeding grounds changes too rapidly or too slowly, the result could be an increased temporal mismatch with food resources (Inouye et al., 2000; Sanz et al., 2003; Strode, 2003; Pearce-Higgins, Yalden \& Whittingham, 2005; Visser \& Both, 2005). This might lead to reduced fitness (Both et al., 2006; Visser, Holleman \& Gienapp, 2006), and to a nonadaptive response to climate change (Both \& Visser, 2001; Coppack \& Both, 2002).

For species breeding at intermediate and high latitudes, arriving early in spring could be costly, due to low food abundance and periods of cold weather causing mass mortality (Brown \& Brown, 2000; Newton, 2007) or temporary return migration (Vepsäläinen, 1968; Richardson, 1978). Arriving too late may also have fitness consequences due to poor matching with peak food abundance (Both et al., 2009) and difficulties in acquiring high-quality breeding sites and/or partner(s) (Alatalo, Lundberg \& Glynn, 1986; Smith \& Moore, 2005; Sergio et al., 2007; Newton, 2008). Fitness consequences of the timing of arrival are therefore expected to be high, with penalties both for being too early or too late, resulting in stabilizing selection pressures (Møller et al., 2009a). If the temporal mismatch with phenology of underlying trophic levels increases, we expect this selection pressure to change over time (Møller, 2007b), either favouring birds arriving earlier than average (if the population advances too little) or later than average (if the population advances too much) (Visser, Both \& Lambrechts, 2004).

There are, however, few studies explicitly addressing effects of climate change on trophic mismatches for migratory species. Two studies showed increased mismatch due to breeding dates advancing less (Both et al., 2009) or more (Pearce-Higgins et al., 2005) than the main food peak for nestlings. In a recent study, an index of likely mismatch was calculated from temperature trends in wintering and breeding areas, and correlated positively with population declines in the Nearctic (Jones \& Cresswell, 2010). Moreover, a study of 117 migratory bird species in Northern Europe (Saino et al., 2010) showed that birds now arrive at higher degree-days than in the past, suggesting that ecological mismatch at time of arrival has increased despite earlier arrival dates. Species for which larger increase of heat accumulation at arrival has been recorded also showed the largest population declines. Fluctuating fitness consequences of arrival date have been demonstrated for a barn swallow population without accurate data on food phenology (Møller, 2007b). For pied flycatchers breeding in the Netherlands, selection for early breeding also became progressively stronger over the years (Both \& Visser, 2001), but the response to climate change appears to be insufficient, probably because spring arrival did not advance (Both \& Visser, 2001; Both et al., 2005). Unequal temperature change during the course of spring could uncouple the cues for the start of breeding (early spring temperature) and the reproductive consequences determined by a food peak later in the season (depending on temperatures after start of breeding) (Visser et al., 2004), particularly if the time lag is long. Long-distance migrants may be particularly vulnerable, due to a longer sequence of decisions preceding and determining the start of reproduction, beginning with 
preparations for migration on the wintering grounds. The value of temperature as a cue does, however, depend on propagation of phenological effects through the food chain (Visser \& Both, 2005; Bretagnolle \& Gillis, 2010; Thackeray et al., 2010), and direct effects of temperatures might have been overlooked (Visser \& Sanz, 2009; Visser, Holleman \& Caro, 2009a).

Despite the strong interest in possible trophic mismatches, support for this claim is still limited. Few empirical studies have addressed the claim in detail. A proper assessment of whether responses are adaptive or not requires estimating fitness consequences not just of breeding date, but also of arrival date and spring migration timing. Since there are yet almost no available data of sufficient detail, we have only just begun to understand these issues. Mismatches may also extend to other ecological relationships, including interspecific competition and host-parasite interactions (Claim 10, Section IV.3), and climatic effects on single predator-prey interactions need to be considered in the context of a web of interacting species (Tylianakis et al., 2008; Bretagnolle \& Gillis, 2010).

\section{(2) Glaim 9: climate change causes population declines in migratory birds}

Strong population declines have been reported for longdistance migrants both in Europe and North America over recent decades (Robbins et al., 1989; Berthold et al., 1998; Holmes \& Sherry, 2001; Sanderson et al., 2006; Heldbjerg $\&$ Fox, 2008), and climate change is likely to be one of multiple causes (Sanderson et al., 2006; Lemoine et al., 2007a; Valiela \& Martinetto, 2007; Møller, Rubolini \& Lehikoinen, 2008; Newton, 2008; Van Turnhout et al., 2010). Partly, population declines can result from a failure to respond phenologically to changing spring conditions (Møller et al., 2008; Saino et al., 2010; Claim 8, Section IV.1). On the other hand, population declines will affect some phenological metrics (Appendix 1) and genetic (as well as phenotypic) variability for natural selection to act on (Claims 4 and 5, Sections III. 1 and III.2).

Climate change is likely to have great impacts on population dynamics of birds through effects mediated by local weather. Although conditions either in breeding areas or wintering areas can dominate (Newton, 1998), population regulation in migratory birds is a complex issue due to the multitude of factors involved at various stages in the annual cycle (Newton, 2004, 2006b). Only for a few species do we know how environmental conditions in different seasons affect both survival and reproduction (Sillett, Holmes \& Sherry, 2000). On the wintering grounds, habitat destruction (Sanderson et al., 2006) and habitat deterioration due to climatic fluctuations such as droughts (den Held, 1981; Peach, Baillie \& Underhill, 1991; Baillie \& Peach, 1992; Szép, 1995; Szép et al., 2006) are probably the main factors causing population declines. Rainfall in Africa is likely the most important single climatic factor determining survival in many Palearctic long-distance migrants, and overwinter condition and survival of American redstarts is clearly influenced by rainfall and moisture gradients (Marra et al., 1998; Studds \& Marra, 2005, 2007). For most species we know far too little about their ranges, movements and ecology in winter quarters to predict clearly how changing wintering conditions will affect population dynamics. Our knowledge from the breeding season is far better, and increased trophic mismatches could result in drastic population declines, as shown for pied flycatchers in the Netherlands (Both et al., 2006). Consequences of mismatch can be expected to depend on the seasonality of the habitat and differential climatic effects (Schaefer et al., 2006; Both et al., 2010), but although some general patterns of population trends according to habitat have been suggested, they are not established (Robbins et al., 1989; Sanderson et al., 2006; Møller et al., 2008; Newton, 2008).

Limiting factors associated with population trends have so far mostly been localized to the breeding season for North American birds and to the winter season for European birds (Newton, 2008), although the combination of effects over the annual cycle remains poorly investigated (Faaborg et al., $2010 a, b)$. There are recent indications of climate change becoming more important than land-use changes (Lemoine et al., 2007a; Møller et al., 2008; Newton, 2008), but such factors are likely to interact (Brook, Sodhi \& Bradshaw, 2008; Darling \& Coté, 2008; Brotons \& Jiguet, 2010). Habitat associations, diet and a number of life-history traits are likely candidates for explaining population trends (Sanderson et al., 2006; Thaxter et al., 2010; Van Turnhout et al., 2010). Furthermore, through seasonal interactions (Claim 7, Section III.4; Appendix S2), survival can affect population dynamics at later stages through delayed density dependence (Ratikainen et al., 2008). Effects at one stage can be compensated at another stage; for instance increased mortality during migration can be compensated by increased survival or reproduction at wintering or breeding grounds due to decreased intraspecific competition (Newton, 2008). Efforts should be made towards better incorporation of seasonal interactions and spatiotemporal complexities in the study of population regulation in migratory birds (Webster \& Marra, 2005).

In sum, climate change has been shown to affect population trends, and is likely to be one important cause for current population declines. Very few studies have addressed how multiple factors affect declines, and there is so far insufficient knowledge to predict whether populations of long-distance migrants in general are more vulnerable to climate change than those of short-distance migrants or resident species (see also Claims 2, 4 and 7, Sections II.2, III. 1 and III.4).

\section{(3) Glaim 10: climate change affects community composition}

Considering the observations of range shifts (Claim 3, Section II.3) and concerted population declines (Claim 9, Section IV.2), it has not surprisingly been claimed that climate change can affect community composition (BöhningGaese \& Lemoine, 2004), and in particular the balance between migratory and resident species in temperate and 
northern breeding bird communities (Lemoine \& BöhningGaese, 2003).

Two main pathways for climate effects have been suggested (Böhning-Gaese \& Lemoine, 2004): one through range shifts and regional population trends, and one through interspecific interactions on the breeding grounds. While there is empirical support for the former mechanism, the effect of changing interspecific interactions on the breeding grounds has been little studied. Although effects of climate change on predation risk (Niehaus \& Ydenberg, 2006; Bretagnolle \& Gillis, 2010) and parasitism levels (Møller, de Lope \& Saino, 2004a; Møller, 2009; Saino et al., 2009; Merino \& Møller, 2010; Douglas et al., 2010, Møller et al., $2010 b$ ) have also been addressed, the main focus has been on competition. Specifically, mild winters are expected to lower the proportion of migrants and increase the survival of residents, resulting in migrants experiencing increased competition for resources upon arrival (Lemoine \& Böhning-Gaese, 2003) and hence population decline. This hypothesis has so far not been properly evaluated, but analysis of time series of two or more competing species could be helpful (Newton, 1998; Sætre, Post \& Král, 1999; Stenseth et al., 2004; Ahola et al., 2007). Recent reviews suggest the importance of explicit consideration of species interactions for understanding effects of climate change at the community level (Bretagnolle \& Gillis, 2010; Brotons \& Jiguet, 2010).

Few empirical studies have addressed changes in community composition with respect to climate. Case studies from central Europe (Lemoine etal., 2007a; Reif et al., $2008 b)$ confirm population increases in southern species and decreases in northern species, as expected from range shifts. Interactions with habitat change and land-use change were, however, demonstrated (Lemoine et al., 2007a; Reif et al., 2008a), and such changes can potentially confound climate-change effects (Brotons \& Jiguet, 2010). One of these studies (Lemoine et al., 2007a) showed the expected pattern of population declines for long-distance migrants and increases for residents and short-distance migrants, and similar results were found for Dutch breeding birds (Van Turnhout et al., 2010). On the other hand, an analysis of trends from 21 sites across Europe (Lemoine, Schaefer \& Böhning-Gaese, 2007b) showed a pattern of decreases in species richness for short-distance migrants and a weak increase in longdistance migrants. Population trends for 68 passerine species breeding in the Czech Republic were mainly explained by food type and general life-history strategy ('r-selected' versus 'K-selected'), and not by different migratory strategies, but populations of resident species fluctuated more than those of short-distance migrants when controlling for phylogeny (Reif et al., 2010). Hence, empirical support for this claim is so far inconclusive and partly rests upon a mixture of changes in quantitative species composition and communitylevel attributes (Brotons \& Jiguet, 2010), as well as species distribution models substituting space for time (La Sorte et al., 2009) by using species-climate relationships at biogeographic scales (Lemoine \& Böhning-Gaese, 2003; Schaefer, Jetz \&
Böhning-Gaese, 2008). Projections based on climate-change scenarios do not yet indicate clearly whether community change will be mainly due to range shifts (Huntley et al., 2007) or changes in migratory activity (Schaefer et al., 2008); a recent study indicates that the composition of the French breeding bird community is indeed tracking spatiotemporal shifts in temperature, but is lagging behind changes in climate (Devictor et al., 2008). If range shifts are species-specific, changes in community composition seem inevitable, though novel combinations of environmental factors resulting in species assemblages without a present-day analogue may or may not be expected from the magnitude of change projected for the $21^{\text {st }}$ Century (Huntley et al., 2007; Stralberg et al., 2009).

Overall, it is clear that climate change can affect the composition of breeding bird communities through range shifts and population trends. It is poorly known to what extent climate-induced community changes are shaped by interspecific interactions, and effects of parasitism, diseases and predation need to be addressed. We can not currently predict whether migrants and residents will be affected differently, nor how different phenological responses between similar species (Sparks \& Tryjanowski, 2007) may transfer to community structure. Changes in community composition outside the breeding season are largely unexplored.

\section{GLAIMS, KNOWLEDGE AND SUPPORT}

Phenological effects of climate change are well documented for birds, the field has been developing quickly, and birds are particularly well-studied organisms - easily raising expectations for consensus views or consistent 'expert opinions'. We therefore performed a simple assessment of our ability to provide such. As with most typical 'expert assessments' of a field, research questions (here, 'claims') are qualitatively different and inter-related, authors are a non-random and non-interchangeable sample of the research community, and the idea of quantitative analysis was conceived at a late stage. Hence, authors (all respondents being active researchers in the field) simply scored their opinion regarding the amount of research effort so far invested in the claim (a rough measure of the amount of 'knowledge', hence hereafter referred to as the 'knowledge basis') and whether the claim holds in general ('support'), individually and separately for each claim, on a continuous scale from 0 (least) to 10 (most). Agreement (concordance) among observers was quantified using correlationbased measures (see online supporting information, Appendix S4).

There was overall stronger support for claims regarding patterns than for possible mechanisms and consequences (Figs 1, 2A). As expected, support correlated positively with the knowledge basis, both when considering mean scores (Fig. 2A; Spearman's rank correlation on mean scores; $\rho=0.65,95 \%$ bootstrap C.I.: $-0.09-1.00, \mathcal{N}=10)$ and individual ratings (Kendall's $\tau=0.47,95 \%$ bootstrap C.I.: 


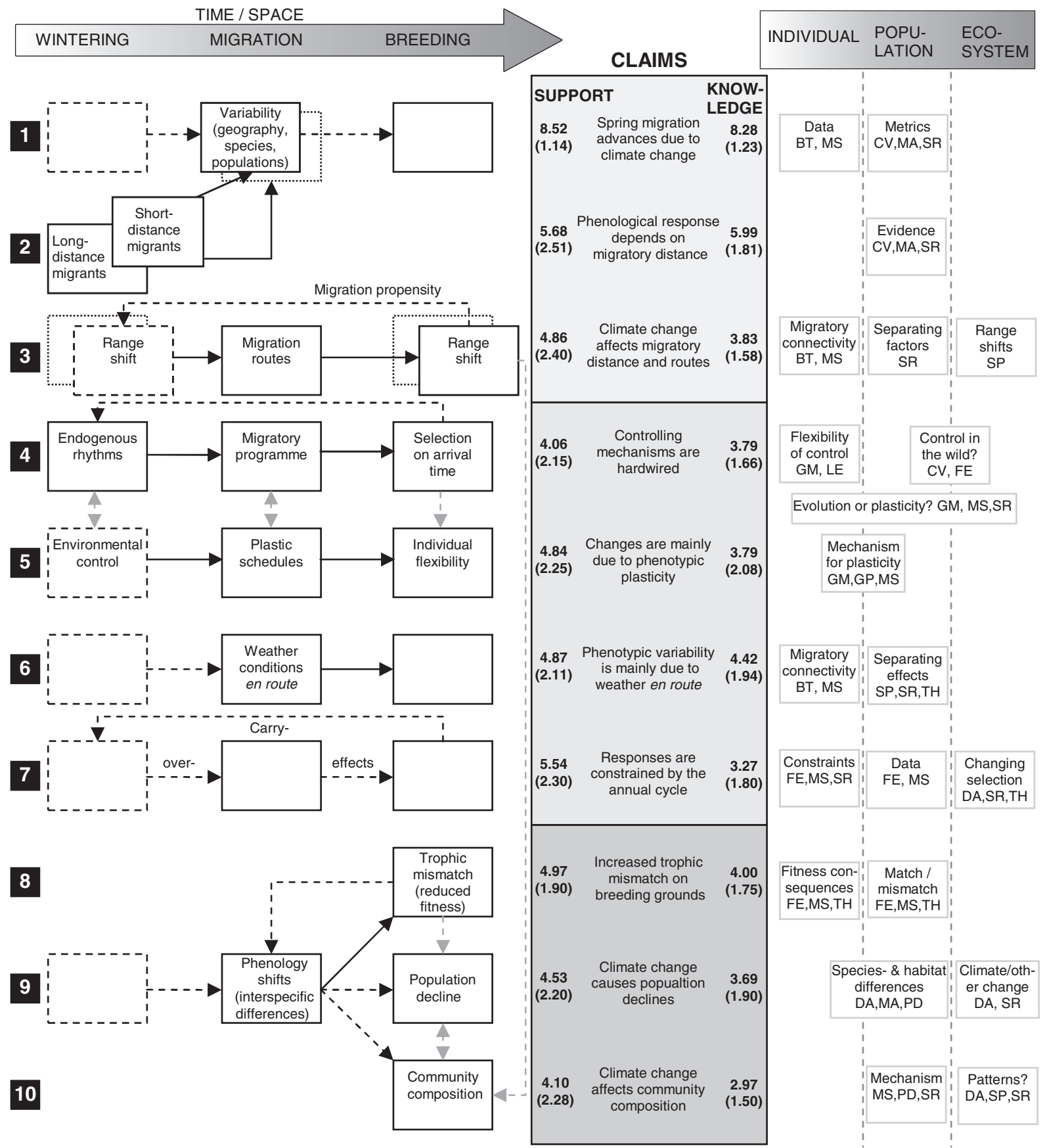

Fig. 1. Claims investigated, overall support, knowledge basis and research challenges. Claims are schematically illustrated to the left; shifts in annual cycle stages are indicated by overlapping boxes, and some links between claims are indicated by arrows. Dashed lines indicate lack of data or uncertain links. In the central column, reported values for support and knowledge basis are the sample mean and standard deviation (in parentheses) of $\mathcal{N}=18$ scores on a scale from 0 to 10 (see main text for details). Some general approaches for meeting research challenges at different levels of biological organization are indicated to the right $(\mathrm{BT}=$ biotelemetry; $\mathrm{CV}=$ cross-validation; $\mathrm{DA}=$ more data; $\mathrm{FE}=$ field experiments; $\mathrm{GM}=$ molecular genetics/genomics; $\mathrm{GP}=$ population genetics; $\mathrm{LE}=$ laboratory experiments; $\mathrm{MA}=$ meta-analysis; $\mathrm{MS}=$ model systems; $\mathrm{PD}=$ population dynamics; $\mathrm{SP}=\mathrm{spatial}$ distribution models; $\mathrm{SR}=$ statistical refinement; $\mathrm{TH}=$ theory development).

$0.38-0.56, \mathcal{N}=180)$. Many claims appear to be rather poorly investigated, and some of these scored higher for support than expected on basis on their knowledge score (Fig. 2A). The level of knowledge about an issue is often poorly communicated to those outside the research community. This is potentially problematic - the less we know about a matter, the less we tend to agree (Fig. 2B) when asked for our 'expert opinion', and the less we agree, 

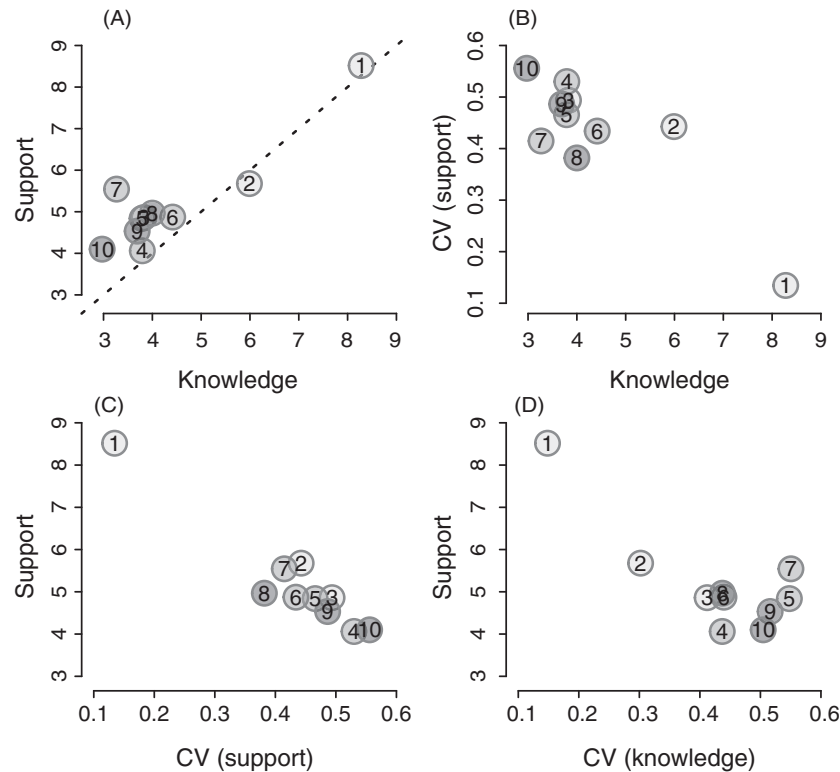

Fig. 2. Selected scatterplots based on summary statistics for $\mathcal{N}=18$ scores for 'knowledge' and 'support' for the 10 claims, showing how (A) support and (B) between-researcher variability in support is related to the amount of knowledge, as well as how support relates to between-researcher variability in $(\mathrm{C})$ support and (D) knowledge. Plot symbols are annotated with claim numbers, and their shading indicates whether the claim was classified as 'pattern', 'mechanism' or 'consequence' (see also Fig. 1). The dotted line in A shows the ' $45^{\circ}$ line' where mean scores for knowledge and support are equal.

the less overall support we give a claim in a consensus assessment (Fig. 2C,D).

Analysis of concordance in scorings showed overall weak agreement between the 18 researchers regarding support (Lin's multiple-group correlation $\rho_{\mathrm{c}}=0.34$, $95 \%$ bootstrap C.I.: $(0.03-0.49)$. In less than one of five cases were two researchers more likely to agree than to disagree regarding which of two claims were most supported (Kendall's $\tau=0.17,95 \%$ bootstrap C.I.: 0.14-0.20). Agreement regarding the knowledge basis was moderate (multiple-group $\rho_{\mathrm{c}}=0.57,95 \%$ C.I.: $0.04-0.62)$. However, agreement was largely restricted to observed patterns (claims 1-3); when excluding these, there was no concordance in the scoring of support $\left(\rho_{\mathrm{c}}=0.06\right)$ and knowledge basis $\left(\rho_{\mathrm{c}}=0.06\right)$. Disagreement between researchers from different disciplines and lines of research is one likely reason for this, and there is a need for unravelling the mechanistic basis of the observed patterns in order to assess potential consequences of climate change. Between-researcher differences in the use of the scoring scale do not appear important; when comparing Kendalls coefficient of concordance to Lin's correlation (for all claims), we obtained similar results for support ( $W=$ 0.33, $95 \%$ bootstrap C.I.: $0.06-0.64)$, but somewhat lower concordance for effort $(W=0.43,95 \%$ bootstrap C.I.: $0.06-0.79)$.

\section{GONGLUSIONS}

(1) In general, patterns of phenological change in spring migration seem to be well established for birds breeding in Europe and Northern America, with exception of the departure pattern of long-distance migrants from their wintering grounds. Attention could be directed towards mechanisms (including effects of range shifts and migratory routes) by which change can occur, and towards consequences of climate change for individuals, populations and communities. There are, however, interesting biological patterns (e.g. differential migration; Appendix S1) and methodological issues (Appendix 1) that need further attention, and more effort should be put into making the best possible use of the large amounts of data being collected and compiled.

(2) Whether organisms will be able to cope with rapid climate change or not will depend on the rates of adaptive response. Hence, one of the pressing issues is to resolve mechanisms of adaptive change - for instance, to what extent changes in the timing of migration are due to microevolutionary change, changes in migration conditions, or behavioural plasticity in the response to the environment (Sheldon, 2010). This will require collaboration bridging gaps across biological disciplines such as genetics, physiology and ecology (Pertoldi \& Bach, 2007; Chown et al., 2010; Visser et al., 2010). The molecular genetic basis regulating the timing of migration remains unknown, but recent progress has been made towards identifying genes potentially regulating the timing of reproduction in partial migrants (see Liedvogel et al., 2009). If good individual-level data are available, quantitative genetics models can be applied, and advanced methods for disentangling variance components such as those sorting under the term 'animal models' (Postma, 2010) seem promising. There is also a need for reconciling field studies with experimental approaches, and the huge literature of older experimental work (Berthold, 1984, 1996, 2001) on the behaviour and physiology of migratory birds should be more properly considered in terms of climate-change issues. More knowledge on the evolution of movement patterns and flexibility of the annual cycle in light of long-term climate variability is also needed, and can be achieved along lines of palaeobiological, phylogeographic and phylogenetic comparative studies. It should not be forgotten that regular migration is only one strategy for largescale movement; seemingly different alternative strategies such as nomadism and irruptive migration may share the same set of basic control mechanisms (Newton, 2006a, 2008; Jonzén et al., 2011).

(3) In order properly to address population-level consequences of climate change, migration needs to be considered in its ecological and evolutionary context, which includes the temporal structure of all important lifecycle stages, as well as frequency- and density-dependent effects within and across trophic levels. Theoretical advancements geared towards climate change (Appendix S3), as well as a fuller and more proper integration 
of diverse frameworks (such as match-mismatch, optimal migration behaviour, genetic change, population dynamics and seasonal interactions), can provide helpful steps in this direction. Technological developments (Robinson et al., 2010) will increasingly allow scientists to follow individual birds through the annual cycle, filling in parts of the enormous gap in knowledge on winter distributions, migratory routes and migratory connectivity of individuals and populations. Important mechanistic issues are, however, likely to remain unclear for a while yet, and species distribution models coupled with global change scenarios may be helpful for gaining new insight even if these tools are based on sweeping assumptions and not yet based on a detailed mechanistic understanding (Wiens et al., 2009; LaSorte \& Jetz, 2010). More generally, there is a need for integration across lines of research and cross-checking of results derived using different data sources or approaches.

(4) An assessment of concordance among the group of researchers revealed poor agreement regarding the support for most claims, but a somewhat better agreement regarding the knowledge basis, enabling consensus regarding broad patterns and likely causes. With increasing knowledge, the overall support for a claim increased and between-researcher variability in support decreased. Although we as researchers would expect this, the outside world is often considerably more interested in the state of the world than in the state of our knowledge, and often expects us to provide robust consensus views and consistent expert opinions. Our overall low capability to provide a consensus view suggests that even for well-studied organisms, there can be substantial challenges in reaching the required level of knowledge.

(5) Society's call for actions facing climate change has in large been met by biologists in a phenomenological manner, focused on changes in distributions, timing, population levels and ecosystem fluxes. For well-studied organisms such as migratory birds, modern biology (being quantitative and technologically advanced) here meets the wealth of detailed biological knowledge acquired through centuries of natural history research. Integrative biology in this interface is challenging in terms of balancing detail and generality (Appendix 2), but rewarding in terms of providing scientific understanding on how organisms balance environmental changes across the life cycle, and how genetic, physiological, behavioural and ecological aspects of the organism interact in environments subject to changing evolutionary forces. Hence, efforts to assess the knowledge basis and synthesize the literature may be important first steps for more unified and robust attempts at predicting climate-change effects.

\section{AGKNOWLEDGEMENTS}

E.K., A.L., N.J., L.B., T.E., N.C.S. and two meetings were partially funded by NordForsk through the Nordic Centre of Excellence EcoClim. We thank collaborators and field workers inside and outside academia for thought-provoking long-term data and discussions, and the reviewers for comments and suggestions that helped improve the manuscript.

\section{APPENDICES}

\section{(1) Data on timing of bird migration}

The choice of a metric for timing of bird migration has largely been based on availability of data. Dates of first arrival to the breeding area and mean/median migration dates from bird observatories along the migratory route are the most frequently recorded (Lehikoinen et al., 2004). Many sources of noise and bias have been identified in these data (Sparks, Roberts \& Crick, 2001; Lehikoinen et al., 2004; Knudsen et al., 2007). The latent phenological distribution of arrival, which can be seen as a population-level life-history trait, is not directly observable and is typically ignored in phenological studies. The shape of this distribution will be modified by migration conditions (with individual phenotypically plastic responses) and mortality during migration, resulting in the realized distribution of arrival.

The most frequently used metric is first arrival date, usually derived from observational data collected by amateurs. This is likely to be only weakly representative of the underlying realized phenological distribution, and the metric is sensitive to variable sampling effort and expected to vary greatly by chance if the distribution is thin-tailed (Sparks et al., 2001; Miller-Rushing, Inouye \& Primack, 2008 $a$; Moussus, Juillard \& Jiguet, 2010). Sampling effort is usually not controllable and may induce systematic bias due to increasing effort over time, and noise due to higher effort during weekends (Sparks, Huber \& Tryjanowski, 2008). First arrival dates are directly negatively related to population size, since the probability of one bird migrating early increases with the number of individuals (Sparks et al., 2001; Miller-Rushing et al., 2008b). The relationship between first arrival dates and population size or observation effort is typically non-linear and depends on distribution shape and location.

Other commonly used metrics of phenology are sample mean or median arrival dates, or other sample quantiles. Typically, these metrics are derived from ringing or observation data at bird observatories. These estimates are usually unbiased with respect to population size, and sampling effort is usually standardized. Some sampling problems do, however, persist, especially for uncommon species and low or high sample quantiles, and as the data usually record birds on stop-over rather than migration, the representation of the data at some localities can be questioned. Bias correction is hard, and the best option may be robust modelling of the arrival distribution (Knudsen et al., 2007), in order to account for varying observation effort and weather effects. The geographic origins and destinations of birds observed at bird observatories are largely unknown, and complications in both interpretation and modelling may arise if the data consist of mixtures of populations or population segments, 
particularly if ranges shift (Thomas \& Lennon, 1999) or populations show different trends (Miller-Rushing et al., 2008b).

Individual-level data may allow a better approximation of 'true' arrival. Migratory movements can be tracked for the larger species by use of expensive satellite transmitters or geolocators, but sample sizes are usually small. For intensively studied populations, arrival of individuals can be estimated from male singing activity or first capture dates, but species may be unobtrusive or wide-roaming upon arrival, and arrival is probably best estimated for colonial species (Brown \& Brown, 2000; Møller, 2008). Such data do, however, allow for better examination of the underlying arrival distribution (Møller, 2008), and factors such as imperfect detectability and mortality during migration can be addressed by using capture-recapture methodology. A potentially important aspect is to define the scale of arrival at breeding grounds. Many birds might gather to feed and/or move around a wider area to recognize different options, before moving to the actual breeding territories (Newton, 2008).

\section{(2) Perspectives: searching for generality in the phenology of migratory birds}

Despite the large number of studies on climate-change effects on the phenology of migratory birds, the literature suggests that the search for general patterns has been difficult. Climatic effects and selection pressures vary across space, time and microhabitat, and the complex life cycle spans continental scales. This variability and gaps in knowledge add to the complexity of integrative biology properly considering ecological and evolutionary processes at all organizational levels of organisms, from genes to ecosystems. Hence, researchers are at risk of being either overly pessimistic ("populations respond idiosyncratically") or overly optimistic ("species respond similarly"). However, generality can be found both along the lines of reductionism and holism. Endogenous control mechanisms do indeed regulate the annual cycle, and modelling of births and deaths at various life-history stages sheds light on how climate change could determine population dynamics, thereby also affecting phenology through seasonal interactions. On the other hand, the large number of studies of a large number of species across a large number of environments shows a great and, as yet, underutilized potential for comparative studies, meta-analyses and studies of phylogenetic and lifehistory constraints. Scaling relationships would be helpful in predicting climate-change consequences - for instance, speed of migration, potential flight range and the time required for moult and breeding scale with body size (Hedenström, 2006, 2008; Rohwer et al., 2009), and in the extension one might address the link between climate and body size, as well as other morphometric traits (Brown \& Brown, 1998; Teplitsky et al., 2008; Salewski, Hochachka \& Fiedler, 2010; Van Buskirk, Mulvihill \& Leberman, 2010), and ask whether small, short-lived species with high demographic turnover are likely to evolve more quickly than longer-lived species.

\section{REFERENGES}

Ahola, M., Laaksonen, T., Eeva, T. \& Lehikoinen, E. (2007). Climate change can alter competitive relationships between resident and migratory birds. Fournal of Animal Ecology 76, 1045-1052.

Ahola, M., Laaksonen, T., Sippola, K., Eeva, T., Rainio, K. \& Lehikoinen, E. (2004). Variation in climate warming along the migration route uncouples arrival and breeding dates. Global Change Biology 10, 1610-1617.

Åkesson, S., Walinder, G., Karlsson, L. \& Ehnbom, S. (2001). Reed warbler orientation: Initiation of nocturnal migratory flights in relation to visibility of celestial cues at dusk. Animal Behaviour 61, 181-189.

Alatalo, R. V., Lundberg, A. \& Glynn, C. (1986). Female pied flycatchers choose territory quality and not male characteristics. Nature 323, 152-153.

Askeyev, O. V., Sparks, T. H. \& Askeyev, I. V. (2009). Earliest recorded Tatarstan skylark in 2008: non-linear response to temperature suggests advances in arrival dates may accelerate. Climate Research 38, 189-192.

Askeyev, O. V., Sparks, T. H., Askeyev, I. V., Tishin, D. V. \& Tryjanowski, P. (2010). East versus West: contrasts in phenological patterns? Global Ecology and Biogeography 19, 783-793.

Askeyev, O. V., Sparks, T. H., Askeyev, I. V. \& Tryjanowski, P. (2007). Is earlier spring migration of Tatarstan warblers expected under climate warming? International Fournal of Biometeorology 51, 459-463.

Baillie, S. R. \& PeAch, W.J. (1992). Population limitation in Palearctic-African migrant passerines. Ibis 134, 120-132.

Balbontín, J., Møller, A. P., Hermosell, I. G., Marzal, A., Reviriego, M. \& DE LOPE, F. (2009). Individual responses in spring arrival date to ecological conditions during winter and migration in a migratory bird. Fournal of Animal Ecology 78, $981-989$.

Barbet-Massin, M., Walther, B. A., Thuiller, W., Rahbek, C. \& Jiguet, F. (2009). Potential impacts of climate change on the winter distribution of AfroPalaearctic migrant passerines. Biology Letters 5, 248-251.

Beaumont, L. J., McAllan, I. A. W. \& Hughes, L. (2006). A matter of timing: Changes in the first date of arrival and last date of departure of Australian migratory birds. Global Change Biology 12, 1339-1354.

Bell, C. P. (2007). Climate change and spring migration in the Yellow Wagtail Motacilla flava: An Afrotropical perspective. Fournal of Ormithology 148 (Suppl 2), S495-S499.

Bensch, S., Grahn, M., Müller, N., Gay, L. \& Åkesson, S. (2009). Genetic, morphological, and feather isotope variation of migratory willow warblers show gradual divergence in a ring. Molecular Ecology 18, 3087-3096.

Berthold, P. (1984). The endogenous control of bird migration - a survey of experimental evidence. Bird Study 31, 19-27.

Berthold, P. (1991). Patterns of avian migration in light of current global 'greenhouse' effects: A central European perspective. In Proceedings of the 20th International Ornithological Congress, pp. 780-786.

Berthold, P. (1996). Control of bird migration. Chapman and Hall, London, United Kingdom.

Berthold, P. (2001). Bird migration: A general survey. Oxford University Press, Oxford, United Kingdom.

Berthold, P., Fiedler, W., Schlenker, R. \& Querner, U. (1998). 25-year study of the population development of central European songbirds: A general decline most evident in long-distance migrants. Naturwissenschaften 85, 350-353.

Berthold, P., Gwinner, E., Klein, H. \& Westrich, P. (1972). Beziehungen zwischen zugunruhe und zugablauf bei Garten- und Mönchsgrasmücke (Sylvia borin und S. atricapilla). Zeitschrift für Tierpsychologie 30, 26-35.

Berthold, P., Helbig, A. J., Mohr, G. \& Querner, U. (1992). Rapid microevolution of migratory behavior in a wild bird species. Nature 360, 668-670.

Böhning-Gaese, K. \& Lemoine, N. (2004). Importance of climate change for the ranges, communities and conservation of birds. Advances in Ecological Research $35,211-236$.

Вотн, C. (2010). Flexibility of timing of avian migration to climate change masked by environmental constraints en route. Current Biology 20, 243-248.

Bотн, C., Bijlsma, R. G. \& Visser, M. E. (2005). Climatic effects on timing of spring migration and breeding in a long-distance migrant, the pied flycatcher Ficedula hypoleuca. Foumal of Avian Biology 36, 368-373.

Both, C., Bouwhuis, S., Lessells, C. M. \& Visser, M. E. (2006). Climate change and population declines in a long-distance migratory bird. Nature 441, 81-83.

Both, C. \& Te Marvelde, L. (2007). Climate change and timing of avian breeding and migration throughout Europe. Climate Research 35, 93-105.

Both, C.,van Asch, M., Bijlsma, R. G., van den Burg, A. B. \& Visser, M. E. (2009). Climate change and unequal phenological changes across four trophic levels: Constraints or adaptations. Fournal of Animal Ecology 78, 73-83.

Both, C., Van Turnhout, C. A. M., Bijlsma, R. G., Siepel, H., Van Strien, A. J. \& Foppen, R. P. B. (2010). Avian population consequences of climate change are most severe for long-distance migrants in seasonal habitats. Proceedings of the Royal Society of London, Series B: Biological Sciences 277, 1259-1266. 
Both, C. \& Visser, M. E. (2001). Adjustment to climate change is constrained by arrival date in a long-distance migrant bird. Nature 411, 296-298.

Bretagnolle, V. \& Gillis, H. (2010). Predator-prey interactions and climate change. In Effects of Climate Change on Birds (eds. A. P. MøLler, W. Fiedler \& P. Berthold), pp. 227-248. Oxford University Press, Oxford, U.K.

Brommer, J. E. (2004). The range margins of northern birds shift polewards. Annales Zoologici Fennici 41, 391-397.

Brommer, J. E. \& Møller, A. P. (2010). Range margins, climate change, and ecology. In Effects of Climate Change on Birds (eds. A. P. Møller, W. Fiedler \& P. Berthold), pp. 275-294. Oxford University Press, Oxford, U.K.

Brook, B. W., Sodhi, N. S. \& Bradshaw, C. J. A. (2008). Synergies among extinction drivers under global change. Trends in Ecology \& Evolution 23, 453-460.

Brotons, L. \& Jiguet, F. (2010). Bird communities and climate change. In Effects of Climate Change on Birds (eds. A. P. Møller, W. Fiedler \& P. Berthold), pp. 275-294. Oxford University Press, Oxford, U.K.

Brown, C. R. \& BRown, M. B. (1998). Intense natural selection on body size and wing and tail asymmetry in cliff swallows during severe weather. Evolution 52, 1461-1475.

Brown, C. R. \& Brown, M. B. (2000). Weather-mediated natural selection on arrival time in cliff swallows (Petrochelidon pyrrhonota). Behavioral Ecology and Sociobiology 47, 339-345.

Butler, C. J. (2003). The disproportionate effect of global warming on the arrival dates of short-distance migratory birds in North America. Ibis 145, 484-495.

Carey, C. (2009). The impacts of climate change on the annual cycles of birds. Philosophical Transactions of the Royal Society of London, Series B: Biological Sciences 364, 3321-3330.

Charmantier, R. H., A. McCleery, Cole, L. R., Perrins, G., Kruuk, L. E. B. \& Sheldon, B. C. (2008). Adaptive phenotypic plasticity in response to climate change in a wild bird population. Science $\mathbf{3 2 0}, 800-803$.

Chernetsov, N., Berthold, P. \& Querner, U. (2004). Migratory orientation of first-year white storks (Ciconia ciconia): Inherited information and social interactions. Journal of Experimental Biology 207, 937-943.

Chernetsov, N., Kishkinev, D. \& Mouritsen, H. (2008). A long-distance avian migrant compensates for longitudinal displacement during spring migration. Current Biology 18, 188-190.

Chown, S. L., Hoffmann, A. A., Kristensen, T. N., Angilletta, M. J., Jr., Stenseth, N. C. \& Pertoldi, C. (2010). Adapting to climate change: a perspective from evolutionary physiology. Climate Research 43, 3-15.

Cochran, W. W., Wikelski, M., Greenberg, R. \& Marra, P. P. (2005). Individual migratory tactics of New World Catharus thrushes: Current knowledge and future tracking options from space. In Birds of two worlds: The ecology and evolution of migration (eds. R. Greenberg \& P. P. Marra), pp. 274-289. Johns Hopkins University Press, Baltimore, Maryland, U.S.A.

Conklin, J. R., Battley, P. F., Potter, M. A. \& Fox, J. W. (2010). Breeding latitude drives individual schedules in a trans-hemispheric migrant bird. Nature Communications 1, 67.

Coppack, T. \& Вотн, C. (2002). Predicting life-cycle adaptation of migratory birds to global climate change. Ardea $\mathbf{9 0}, 369-378$

Coppack, T. \& Pulido, F. (2004). Photoperiodic response and the adaptability of avian life cycles to environmental change. Advances in Ecological Research 35, 131-150.

Coppack, T., Pulido, F. \& Berthold, P. (2001). Photoperiodic response to early hatching in a migratory bird species. Oecologia 128, 181-186.

Coppack, T., Tindemans, I., Czischz, M., Van der Linden, A., Berthold, P. \& Pulido, F. (2008). Can long-distance migratory birds adjust to the advancement of spring by shortening migration distance? The response of the pied flycatcher to latitudinal photoperiodic variation. Global Change Biology 14, 2516-2522.

Cotton, P. A. (2003). Avian migration phenology and global climate change. Proceedings of the National Academy of Sciences, USA 100, 12219-12222.

Darling, E. S. \& CotÉ, I. M. (2008). Quantifying the evidence for ecological synergies. Ecology Letters 11, 1278-1286.

DEN HeLd, J. J. (1981). Population changes in the purple heron in relation to drought in the wintering area. Ardea 69, 185-191.

Devictor, V., Julliard, R., Couvet, D. \& Jiguet, F. (2008). Birds are tracking climate warming, but not fast enough. Proceedings of the Royal Society of London, Series B: Biological Sciences 275, 2743-2748.

Doswald, N., Willis, S. G., Collingham, Y. C., Pain, D. J., Green, R. E. \& Huntley, B. (2009). Potential impacts of climatic change on the breeding and non-breeding ranges and migration distance of European Sylvia warblers. Fournal of Biogeography 36, 1194-1208.

Douglas, D. J. T., Newson, S. E., Leech, D. I., Noble, D. G. \& Robinson, R. A. (2010). How important are climate-induced changes in host availability for population processes in an obligate brood parasite, the European cuckoo? Oikos 119, 1834-1840.

Erni, B., Liechti, F., Underhill, L. G. \& Bruderer, B. (2002). Wind and rain govern the intensity of nocturnal bird migration in central Europe - A log-linear regression analysis. Ardea 90, 155-166.

Faaborg,J., Holmes, R. T., Anders, A. D., Bildstein, K. L., Dugger, K. M., Gauthreaux, S. A., Jr., Heglund, P., Hobson, K. A., Jahn, A. E., Johnson, D. H., Latta, S. G., Levey, D. J., Marra, P. P., Merkord, C. L., Nol, E.,
Rothstein, S. I., Sherry, T. W., Sillett, T. S., Thompson, F. R., III \& WARNOCK, N. (2010a). Conserving migratory land birds in the New World: Do we know enough? Ecological Applications 20, 398-418.

Faaborg, J., Holmes, R. T., Anders, A. D., Bildstein, K. L., Dugger, K. M., Gauthreaux, S. A., Jr., Heglund, P., Hobson, K. A., Jahn, A. E., Johnson, D. H., Latta, S. C., Levey, D. J., Marra, P. P., Merkord, C. L., Nol, E., Rothstein, S. I., Sherry, T. W., Sillett, T. S., Thompson, F. R., III \& WARNOCK, N. (2010b). Recent advances in understanding migration systems of New World land birds. Ecological Monographs 80, 3-48.

FIEDLER, W. (2003). Recent changes in migratory behaviour of birds: A compilation of field observations and ringing data. In Avian migration (eds. P. BerTHOLD, E. Gwinner \& E. Sonnenschein), pp. 21-38. Springer, Berlin, Germany.

Fiedler, W., Bairlein, F. \& Koppen, U. (2004). Using large-scale data from ringed birds for the investigation of effects of climate change on migrating birds: pitfalls and prospects. Advances in Ecological Research 35, 49-67.

Forchhammer, M. C.. Post, E. \& Stenseth, N. C. (2002). North Atlantic Oscillation timing of long- and short-distance migration. Fournal of Animal Ecology 71, 1002-1014.

Gienapp, P., Leimu, R. \& Merilä, J. (2007). Responses to climate change in avian migration time - microevolution versus phenotypic plasticity. Climate Research $35,25-35$.

Gienapp, P., Teplitsky, C., Alho, J. S., Mills, J. A. \& Merilä, J. (2008). Climate change and evolution: Disentangling environmental and genetic responses. Molecular Ecology 17, 167-178.

Gill, J. A., Norris, K., Potts, P. M., Gunnarsson, T. G., Atkinson, P. W. \& SutherLand, W. J. (2001). The buffer effect and large scale regulation in migratory birds. Nature 412, 436-438.

Gitay, H., Suárez, A., Watson, R. T. \& Dokken, D. J., eds. (2002). Climate change and biodiversity. IPCC Technical Paper V. Intergovernmental Panel on Climate Change (IPCC), Geneva, Switzerland.

Goodenough, A. E., Hart, A. G. \& StafFord, R. (2010). Is adjustment of breeding phenology keeping pace with the need for change? Linking observed response in woodland birds to changes in temperature and selection pressure. Climatic Change 102, 687-697.

Gordo, O. (2007). Why are bird migration dates shifting? A review of weather and climate effects on avian migratory phenology. Climate Research 35, 37-58.

Gordo, O., Brotons, L., Ferrer, X. \& Comas, P. (2005). Do changes in climate patterns in wintering areas affect the timing of the spring arrival of trans-Saharan migrant birds? Global Change Biology 11, 12-21.

Gordo, O. \& Sanz, J. J. (2006). Climate change and bird phenology: A long-term study in the Iberian Peninsula. Global Change Biology 12, 1993-2004.

Gordo, O. \& SAnZ, J. J. (2008). The relative importance of conditions in wintering and passage areas on spring arrival dates: the case of long-distance Iberian migrants. Fournal of Ornithology 149, 199-210.

Gunnarsson, T. G., Gill, J. A., Atrinson, P. G., Gélinaud, G., Ротts, P. M., Croger, R. E., Gudmundsson, G. A., Appleton, G. F. \& Sutherland, W. J. (2006). Population-scale drivers of individual arrival times in migratory birds. Fournal of Animal Ecology 75, 1119-1127.

Gunnarsson, T. G., Gill, J. A., Newton, J., Potts, P. M. \& Sutherland, W. J (2005). Seasonal matching of habitat quality and fitness in migratory birds. Proceeding. of the Royal Society of London, Series B: Biological Sciences 272, 2319-2323.

GwINNER, E. (1968). Artspezifische muster der zugunruhe bei laubsängern und ihre mögliche bedeutung für die beendigung des zuges im winterquartier. Zeitschrift für Tierpsychologie 25, 843-853.

Gwinner, E. (1986). Circannual rhythms: Endogenous annual clocks in the organization of seasonal processes. Springer, Berlin, Germany.

Gwinner, E. (1996). Circadian and circannual programmes in avian migration. Fournal of Experimental Biology 199, 39-48.

Hedenström, A. (2006). Scaling of migration and the annual cycle of birds. Ardea 94, 399-408.

Hedenström, A. (2008). Adaptations to migration in birds: Behavioural strategies, morphology and scaling effects. Philosophical Transactions of the Royal Society of London, Series B: Biological Sciences 363, 287-299.

Hedenström, A. \& Alerstam, T. (1995). Optimal flight speed of birds. Philosophical Transactions of the Royal Society of London, Series B: Biological Sciences 348, 471-487.

Heldbjerg, H. \& Fox, T. A. D. (2008). Long-term population declines in Danish trans-Saharan migrant birds. Bird Study 55, 267-279.

Helm, B. \& GWinNer, E. (2006). Migratory restlessness in an equatorial nonmigratory bird. PLoS Biology 4, 611-614.

Helm, B., Schwabl, I. \& Gwinner, E. (2009). Circannual basis of geographically distinct bird schedules. Fournal of Experimental Biology 212, 1259-1269.

Helm, B. \& Visser, M. E. (2010). Heritable circadian period length in a wild bird population. Proceedings of the Royal Society of London, Series B: Biological Science. 277, 3335-3342

Hendry, A. P., Farrugia, T. J. \& Kinnison, M. T. (2008). Human influences on rates of phenotypic change in wild animal populations. Molecular Ecology 17, 20-29. 
Herrmann, S. M., Anyamba, A. \& Tucker, C. J. (2005). Recent trends in vegetation dynamics in the African Sahel and their relationship to climate. Global Environmental Change 15, 394-404.

Hitch, A. T. \& Leberg, P. L. (2007). Breeding distributions of North American bird species moving north as a result of climate change. Conservation Biology 21, 534-539.

Holmes, R. T. \& Sherry, T. W. (2001). Thirty-year bird population trends in an unfragmented temperate deciduous forest: Importance of habitat change. Auk 118, 589-609.

Hötкer, H. (2002). Arrival of pied avocets Recurvirostra avosetta at the breeding site: Effects of winter quarters and consequences for reproductive success. Ardea 90, 379-387.

HubÁLEK, Z. (2004). Global weather variability affects avian phenology: A long-term analysis, 1881-2001. Folia Zoologica 53, 227-236.

Hulme, M., Doherty, R., Ngara, T., New, M. \& Lister, D. (2001). African climate change: 1900-2100. Climate Research 17, 145-168.

Huntley, B., Green, R. E., Collingham, Y. C. \& Willis, S. G. (2007). A climatic atlas of European breeding birds. Durham University, RSPB, and Lynx Edicions, Barcelona, Spain.

HüPpOP, O. \& HüPPOP, K. (2003). North Atlantic Oscillation and timing of spring migration in birds. Proceedings of the Royal Society of London, Series B: Biological Sciences 270, 233-240.

HüPPOP, O. \& WinkEL, W. (2006). Climate change and timing of spring migration in the long-distance migrant Ficedula hypoleuca in central Europe: The role of spatially different temperature changes along migration routes. Fournal of Ornithology 147, 344-353.

Inouye, D. W., Barr, B., Armitage, K. B. \& Inouye, B. D. (2000). Climate change is affecting altitudinal migrants and hibernating species. Proceedings of the National Academy of Sciences, USA 97, 1630-1633.

IPCC (2007). Climate Change 2007: Impacts, Adaptation and Vulnerability. Contribution of Working Group II to the Fourth Assessment Report of the Intergovernmental Panel on Climate Change. Cambridge University Press, Cambridge, United Kingdom.

Jones, T. \& Cresswell, W. (2010). The phenology mismatch hypothesis: are declines of migrant birds linked to uneven global climate change? Fournal of Animal Ecology 79, 98-108.

Jonzén, N., Knudsen, E., Holt, R. \& SÆther, B. E. (2011). Uncertainty and predictability: the niches of migrants and nomads. In Animal Migration: A Synthesis (eds. E. J. Milner-Gulland, J. M. Fryxell \& A. R. E. Sinclair), pp. 91-109. Oxford University Press.

Jonzén, N., Lindén, A., Ergon, T., Knudsen, E., Vik, J. O., Rubolini, D., Piacentini, D., Brinch, C., Spina, F., Karlsson, L., Stervander, M., Andersson, A., Waldenström, J., Lehikoinen, A., Edvardsen, E., Solvang, R. \& Stenseth, N. C. (2006). Rapid advance of spring arrival dates in long-distance migratory birds. Science 312, 1959-1961.

Jonzén, N., Lindén, A., Ergon, T., Knudsen, E., Vik, J. O., Rubolini, D., Piacentini, D., Brinch, G., Spina, F., Karlsson, L., Stervander, M., Andersson, A., Waldenström, J., Lehikoinen, A., Edvardsen, E., Solvang, R. \& Stenseth, N. C. (2007). Response to comment on "Rapid advance of spring arrival dates in long-distance migratory birds". Science 315, 598c.

Karlsen, S. R., H, K. A., Wielgolaski, F. E., Tolvanen, A., T, H., PoikoLAinen, J. \& Kubin, E. (2009). Growing-season trends in Fennoscandia 1982-2006, determined from satellite and phenology data. Climate Research 39, 275-286.

Knudsen, E., Lindén Ergon, T., Jonzén, N., Vik, J. O., Knape, J., Røer, J. E. \& STENSETh, N. C. (2007). Characterizing bird migration phenology using data from standardized monitoring at bird observatories. Climate Research 35, 59-77.

KoK, O. B., van Ee, C. A. \& NeL, D. G. (1991). Daylength determines departure date of the spotted flycatcher Muscicapa striata from its winter quarters. Ardea 79, 63-65.

Kокко, Н. (1999). Competition for early arrival in migratory birds. Fournal of Animal Ecology 68, 940-950.

LA Sorte, F. A. \& JETz, W. (2010). Avian distributions under climate change: towards improved projections. Fournal of Experimental Biology 213, 862-869.

La Sorte, F. A., Lee, T. M., Wilman, H. \& Jetz, W. (2009). Disparities between observed and predicted impacts of climate change on winter bird assemblages. Proceedings of the Royal Society of London, Series B: Biological Sciences 276, 3167-3174.

La Sorte, F. A. \& Thompson, F. R. (2007). Poleward shifts in winter ranges of North American birds. Ecology 88, 1803-1812.

LACK, D. (1968). Ecological adaptations for breeding in birds. Methuen, London.

Lehikoinen, E. \& Sparks, T. H. (2010). Changes in migration. In Effects of Climate Change on Birds (eds. A. P. Møller, W. Fiedler \& P. Berthold), pp. 89-112. Oxford University Press, Oxford, U.K.

Lehikoinen, E., Sparks, T. H. \& Zalakevicius, M. (2004). Arrival and departure dates. Advances in Ecological Research 35, 1-31.

Lemoine, N., Bauer, H. G., Peintinger, M. \& Böhning-Gaese, K. (2007a). Effects of climate and land-use change on species abundance in a central European bird community. Conservation Biology 21, 495-503.

Lemoine, N. \& Böhning-Gaese, K. (2003). Potential impact of global climate change on species richness of long-distance migrants. Conservation Biology 17, 577-586.
Lemoine, N., Schaefer, H. C. \& Böhning-Gaese, K. (2007b). Species richness of migratory birds is influenced by global climate change. Global Ecology and Biogeography 16, $55-64$.

Liedvogel, M., Szulkin, M., Knowles, S. C. L., Wood, M. J. \& Sheldon, B. C. (2009). Phenotypic correlates of Clock gene variation in a wild blue tit population: evidence for a role in seasonal timing of reproduction. Molecular Ecology 18, 2444-2456.

Loxton, R. G. \& Sparks, T. H. (1999). Arrival of spring migrants at Portland, Skokholm, Bardsey and Calf of Man. Bardsey Observatory Report 42, 105-143.

Maclean, I. M. D., Austin, G. E., Rehfisch, M. M., Blew, J., Crowe, O., Delany, S., Devos, K., Deceuninck, B., Guenther, K., Laursen, K., Van Roomen, M. \& WAHL, J. (2008). Climate change causes rapid changes in the distribution and site abundance of birds in winter. Global Change Biology 14, 2489-2500.

Marra, P. P., Francis, G. M., Mulvihill, R. S. \& Moore, F. R. (2005). The influence of climate on the timing and rate of spring bird migration. Oecologia $142,307-315$.

Marra, P. P., Hobson, K. A. \& Holmes, R. T. (1998). Linking winter and summer events in a migratory bird by using stable-carbon isotopes. Science 282, 1884-1886.

Mason, C. F. (1995). Long-term trends in the arrival dates of spring migrants. Bird Study 42, 182-189.

MenzeL, A. (2000). Trends in phenological phases in Europe between 1951 and 1996. International fournal of Biometeorology 44, 76-81.

Merino, S. \& Møller, A. P. (2010). Host-parasite interactions and climate change. In Effects of Climate Change on Birds (eds. A. P. MøLler, W. Fiedler \& P. BerTHOld), pp. 213-226. Oxford University Press, Oxford, U.K.

Miller-Rushing, A. J., Inouye, D. W. \& Primack, R. B. (2008a). How well do first flowering dates measure plant responses to climate change? The effects of population size and sampling frequency. Fournal of Ecology 96, 1289-1296.

Miller-Rushing, A. J., Lloyd-Evans, T. L., Primack, R. B. \& Satzinger, P. (2008b). Bird migration times, climate change, and changing population sizes. Global Change Biology 14, 1959-1972.

MiLls, A. M. (2005). Changes in the timing of spring and autumn migration in North American migrant passerines during a period of global warming. Ibis 147, 259-269.

MøLLER, A. P. (2007a). Interval between clutches, fitness, and climate change. Behavioral Ecology 18, 62-70.

MøLler, A. P. (2007b). Tardy females, impatient males: Protandry and divergent selection on arrival date in the two sexes of the barn swallow. Behavioral Ecology and Sociobiology 61, 1311-1319.

MøLler, A. P. (2008). Distribution of arrival dates in a migratory bird in relation to environmental conditions, natural selection and sexual selection. Ethology Ecology $\mathbb{E}^{\circ}$ Evolution 20, 193-210.

MøLLER, A. P. (2009). Host-parasite interactions and vectors in the barn swallow in relation to climate change. Global Change Biology $\mathbf{1 6 .}$

Møller, A. P., Balbontín, J., Cuervo, J. J., Hermosell, I. G. \& de Lope, F. $(2009 a)$. Individual differences in protandry, sexual selection, and fitness. Behavioral Ecology 20, 433-440.

Møller, A. P., De Lope, F. \& SAino, N. (2004a). Parasitism, immunity, and arrival date in a migratory bird, the barn swallow. Ecology 85, 206-219.

Møller, A. P., Fiedler, W. \& Berthold, P., eds. (2004b). Birds and climate change. Advances in Ecological Research 35. Elsevier, London, United Kingdom.

Møller, A. P., Flensted-Jensen, E., Klarborg, K., Mardal, W. \& Nielsen, J. T. $(2010 a)$. Climate change affects the duration of the reproductive season in birds. Fournal of Animal Ecology 79, 777-784.

Møller, A. P., Flensted-Jensen, E. \& Mardal, W. (2009b). Adjustment of the annual cycle to climatic change in a long-lived migratory bird species. Current Zoology 55, $92-101$.

Møller, A. P., Rubolini, D. \& Lehikoinen, E. (2008). Populations of migratory bird species that did not show a phenological response to climate change are declining. Proceedings of the National Academy of Sciences, USA 105, 16195-16200.

Møller, A. P., Saino, N., Adamik, P., Ambrosini, R., Antonov, A. D. C., Stokke, B. G., Foss $\varnothing$ y, F., Lehikoinen, E., Martin-Vivaldi, M., Moksnes, A., Moskat, C., Røskaft, E., Rubolini, D., Schulze-Hagen, K., Soler, M. \& SнyкоғF, J. A. (2010b). Rapid change in host use of the common cuckoo Cuculus canorus linked to climate change. Proceedings of the Royal Society of London, Series B: Biological Sciences. Doi: 10.1098/rspb.2010.1592

Mouritsen, H. (2003). Spatiotemporal orientation strategies of long-distance migrants. In Avian migration (eds. P. Berthold, E. Gwinner \& E. Sonnenschein), pp. 493-513. Springer, Berlin, Germany.

Moussus, J. P., Juillard, R. \& Jiguet, F. (2010). Featuring 10 phenological estimators using simulated data. Methods in Ecology and Evolution 1, 140-150.

Murphy-Klassen, H. M., Underwood, T. J., Sealy, S. G. \& Czyrnyj, A. A. (2005). Long-term trends in spring arrival dates of migrant birds at Delta Marsh, Manitoba, in relation to climate change. Auk 122, 1130-1148.

NajManová, L. \& ADAmík, P. (2009). Effect of climatic change on the duration of the breeding season in three European thrushes. Bird Study 56, 349-356.

Newton, I. (1998). Population limitation in birds. Academic Press, San Diego, California, U.S.A 
Newton, I. (2004). Population limitation in migrants. Ibis 146, 197-226.

Newton, I. (2006a). Advances in the study of irruptive migration. Ardea 94, 433-460.

Newton, I. (2006b). Can conditions experienced during migration limit the population levels of birds? Fournal of Ormithology 147, 146-166.

NewTon, I. (2007). Weather-related mass-mortality events in migrants. Ibis 149, 453-467.

Newton, I. (2008). The migration ecology of birds. Academic Press, London, United Kingdom.

Niehaus, A. C. \& Ydenberg, R. C. (2006). Ecological factors associated with the breeding and migratory phenology of high-latitude breeding western sandpipers. Polar Biology 30, 11-17.

NorRIS, D. R. (2005). Carry-over effects and habitat quality in migratory populations. Oikos 109, 178-186.

Parmesan, C. (2006). Ecological and evolutionary responses to recent climate change. Annual Review of Ecology, Evolution and Systematics 37, 637-669.

Parmesan, C. \& Yohe, G. (2003). A globally coherent fingerprint of climate change impacts across natural systems. Nature 421, 37-42.

Peach, W., Baillie, S. \& Underhill, L. (1991). Survival of British sedge warblers Acrocephalus schoenobaenus in relation to West African rainfall. Ibis 133, 300-305.

Pearce-Higgins, J. W., Yalden, D. W. \& Whittingham, M. J. (2005). Warmer springs advance the breeding phenology of golden plovers Pluvialis apricaria and their prey (Tipulidae). Oecologia 143, 470-476.

Peñuelas, J., Filella, I. \& Comas, P. (2002). Changed plant and animal life cycles from 1952 to 2000 in the Mediterranean region. Global Change Biology 8, 531-544.

Pertoldi, C. \& BaCH, L. A. (2007). Evolutionary aspects of climate-induced changes and the need for multidisciplinarity. Fournal of Thermal Biology 32, 118-124.

Postma, E. (2010). Using animal models to infer and predict the evolutionary consequences of climate change. In Effects of Climate Change on Birds (eds. A. P. Møller, W. Fiedler \& P. Berthold), pp. 47-55. Oxford University Press, Oxford, U.K.

Pulido, F. (2007a). Phenotypic changes in spring arrival: evolution, phenotypic plasticity, effects of weather and condition. Climate Research 35, 5-23.

Pulido, F. (2007b). The genetics and evolution of avian migration. Bioscience 57, $165-174$.

Pulido, F. \& Berthold, P. (2003). Quantitative genetic analysis of migratory behavior. In Avian migration (eds. P. Berthold, E. Gwinner \& E. Sonnenschein), pp. 53-77. Springer, Berlin, Germany.

Pulido, F. \& Berthold, P. (2004). Microevolutionary response to climatic change. Advances in Ecological Research 35, 151-183.

Pulido, F. \& Berthold, P. (2010). Current selection for lower migratory activity will drive the evolution of residency in a migratory bird population. Proceedings of the National Academy of Sciences, USA 107, 7341-7346.

Pulido, F. \& Widmer, M. (2005). Are long-distance migrants constrained in their evolutionary response to environmental change? Causes of variation in the timing of autumn migration in a blackcap (S. atricapilla) and two garden warbler (Sylvia borin) populations. Annals of the New York Academy of Sciences 1046, 228-241.

Ratikainen, I. I., Gill, J. A., Gunnarsson, T. G., Sutherland, W. J. \& Kокко, H. (2008). When density dependence is not instantaneous: Theoretical developments and management implications. Ecology Letters 11, 184-198.

Reif, J., Storch, D., Vorisek, P., Stastny, K. \& Bejcek, V. (2008a). Bird-habitat associations predict population trends in central European forest and farmland birds. Biodiversity and Conservation 17, 3307-3319.

Reif, J., Vermouzek, Z., Vorisek, P., Stastny, K., Bejcek, V. \& Flousek, J. (2010). Population changes in Czech passerines are predicted by their life-history and ecological traits. Ibis 152, 610-621.

Reif, J., Vorisek, P., Stastny, K., Koschova, M. \& Bejcek, V. (2008b). The impact of climate change on long-term population trends of birds in a central European country. Animal Conservation 11, 412-421.

Richardson, W.J. (1978). Timing and amount of bird migration in relation to weather - review. Oikos 30, 224-272.

Robbins, G. S., Sauer, J. R., Greenberg, R. \& Droege, S. (1989). Population declines in North American birds that migrate to the Neotropics. Proceedings of the National Academy of Sciences, USA 86, 7658-7662.

Robinson, W. D., Bowlin, M. S., Bisson, I., Shamoun-Baranes, J., Thorup, K., Diehl, R. H., Kunz, T. H., Mabey, S. \& Winkler, D. W. (2010). Integrating concepts and technologies to advance the study of bird migration. Frontiers in Ecology and the Environment 8, 354-361.

Robson, D. \& Barriocanal, C. (2010). Ecological conditions in wintering and passage areas as determinants of timing of spring migration in trans-Saharan migratory birds. Fournal of Animal Ecology. doi: 10.1111/j.1365-2656.2010.01772.x Roff, D. A. (2002). Life history evolution. Sinauer, Massachusetts, U.S.A.

Rohwer, S., Ricklefs, R. E., Rohwer, V. G. \& Copple, M. M. (2009). Allometry of the Duration of Flight Feather Molt in Birds. PLoS Biology 7, e1000132.

Rosenzweig, C., Karoly, D., Vicarelli, M., Neofotis, P., Wu, Q., Casassa, G., Menzel, A., Root, T. L., Estrella, N., Seguin, B., Tryjanowski, P., Liu, C., Rawlins, S. \& Imeson, A. (2008). Attributing physical and biological impacts to anthropogenic climate change. Nature 453, 353-358.
Rubolini, D., Ambrosini, R., Caffi, M., Brichetti, P.,Armiraglio, S. \& SAINo, N. (2007a). Long-term trends in first arrival and first egg laying dates of some migrant and resident bird species in northern Italy. International fournal of Biometeorology 51, 553-563.

Rubolini, D., Møller, A. P., Rainio, K. \& Lehikoinen, E. (2007b). Intraspecific consistency and geographic variability in temporal trends of spring migration phenology among European bird species. Climate Research 35, 135-146.

Rubolini, D., Saino, N. \& Møller, A. P. (2010). Migratory behaviour constrains the phenological response of birds to climate change. Climate Research 42, 45-55.

Runge, M. C. \& Marra, P. P. (2005). Modeling seasonal interactions in the population dynamics of migratory birds. In Birds of two worlds: The ecology and evolution of migration (eds. R. GreenberG \& P. P. Marra), pp. 375-389. Johns Hopkins University Press, Baltimore, Maryland, U.S.A.

Słtre, G. P., Post, E. \& Král, M. (1999). Can environmental fluctuation prevent competitive exclusion in sympatric flycatchers? Proceedings of the Royal Society of London, Series B: Biological Sciences 266, 1247-1251.

Saino, N. \& Ambrosini, R. (2008). Climatic connectivity between Africa and Europe may serve as a basis for phenotypic adjustment of migration schedules of transSaharan migratory birds. Global Change Biology 14, 250-263.

Saino, N., Ambrosini, R., Rubolini, D., von Hardenberg, J., ProvenZale, A., Hüppop, K., Hüppop, O., Lehikoinen, A., Lehikoinen, E., Rainio, K., Romano, M. \& Sokolov, L. (2010). Climate warming, ecological mismatch at arrival and population decline in migratory birds. Proceedings of the Royal Society of London, Series B: Biological Sciences. Doi: 10.1098/rspb.2010.1778.

Saino, N., Rubolini, D., Jonzén, N., Ergon, T., Montemaggiori, A., Stenseth, N. C. \& SpInA, F. (2007). Temperature and rainfall anomalies in Africa predict timing of spring migration in trans-Saharan migratory birds. Climate Research $35,123-134$.

Saino, N., Rubolini, D., Lehikoinen, E., Sokolov, L. V., Bonisoli-Alquati, A., Ambrosini, R., Boncoraglio, G. \& Møller, A. P. (2009). Climate change effects on migration phenology may mismatch brood parasitic cuckoos and their hosts. Biology Letters 5, 539-541.

Saino, N., Szep, T., Romano, M., Rubolini, D., Spina, F. \& Møller, A. P. (2004). Ecological conditions during winter predict arrival date at the breeding quarters in a trans-Saharan migratory bird. Ecology Letters 7, 21-25.

SAlewski, V., HochachKa, W. M. \& Fiedler, W. (2010). Global warming and Bergmann's rule: do central European passerines adjust their body size to rising temperatures? Oecologia 162, 247-260.

Sanderson, F. J., Donald, P. F., Pain, D. J., Burfield, I. J. \& van BomMEL, F. P. J. (2006). Long-term population declines in Afro-Palearctic migrant birds. Biological Conservation 131, 93-105.

Sanz, J. J., Potti, J., Moreno, J., Merino, S. \& Frías, O. (2003). Climate change and fitness components of a migratory bird breeding in the Mediterranean region. Global Change Biology 9, 461-472.

Schaefer, H. C., Jetz, W. \& BöHning-Gaese, K. (2008). Impact of climate change on migratory birds: Community reassembly versus adaptation. Global Ecology and Biogeography 17, 38-49.

Schaefer, T., Ledebur, G., Beier, J. \& Leisler, B. (2006). Reproductive responses of two related coexisting songbird species to environmental changes: Global warming, competition, and population sizes. Fournal of Ornithology 147, 47-56.

Sergio, F., Blas, J., Forero, M. G., Donázar, J. A. \& Hiraldo, F. (2007). Sequential settlement and site dependence in a migratory raptor. Behavioral Ecology 18, $811-821$.

Shamoun-Baranes, J., Baharad, A., Alpert, P., Berthold, P., Yom-Tov, Y., Dvir, Y. \& Leshem, Y. (2003). The effect of wind, season and latitude on the migration speed of white storks Ciconia ciconia, along the eastern migration route. Journal of Avian Biology 34, 97-104.

Sheldon, B. C. (2010). Genetic perspectives on the micro-evolutionary consequences of climate change in birds. In Effects of Climate Change on Birds (eds. A. P. Møller, W. Fiedler \& P. Berthold), pp. 149-168. Oxford University Press, Oxford, U.K.

Sillett, T. S., Holmes, R. T. \& Sherry, T. W. (2000). Impacts of a global climate cycle on population dynamics of a migratory songbird. Science 288, 2040-2042.

Sinelschikova, A., Kosarev, V., Panov, I. \& Baushev, A. N. (2007). The influence of wind conditions in Europe on the advance in timing of the spring migration of the song thrush (Turdus philomelos) in the south-east Baltic region. International Journal of Biometeorology 51, 431-440.

Smith, R. J. \& Moore, F. R. (2005). Arrival timing and seasonal reproductive performance in a long-distance migratory landbird. Behavioral Ecology and Sociobiology 57, $231-239$.

Sparks, T. H., Aasa, A., Huber, K. \& Wadsworth, R. (2009). Changes and patterns in biologically relevant temperatures in Europe 1941-2000. Climate Research 39, 191-207.

Sparks, T. H., Huber, K. \& Tryjanowski, P. (2008). Something for the weekend? Examining the bias in avian phenological recording. International fournal of Biometeorology 52, 505-510.

Sparks, T. H., Roberts, D. R. \& Crick, H. Q. P. (2001). What is the value of first arrival dates of spring migrants in phenology? Avian Ecology and Behaviour 7, 75-85. 
Sparks, T. H. \& Tryjanowski, P. (2007). Patterns of spring arrival dates differ in two hirundines. Climate Research 35, 159-164.

Stenseth, N. G., Chan, K. S., Tavecchia, G., Coulson, T., Mysterud, A. Clutton-Brock, T. \& Grenfell, B. (2004). Modelling non-additive and nonlinear signals from climatic noise in ecological time series: Soay sheep as an example. Proceedings of the Royal Society of London, Series B: Biological Sciences 271, 1985-1993.

Stenseth, N. G., Mysterud, A., Ottersen, G., Hurrell, J. W., Chan, K. S. \& Lima, M. (2002). Ecological effects of climate fluctuations. Science 297, 1292-1296.

Stenseth, N. G., Ottersen, G., Hurrell, J. W., Mysterud, A., Lima, M., Chan, K. S., Yoccoz, N. G. \& Adlandsvik, B. (2003). Studying climate effects on ecology through the use of climate indices: The North Atlantic Oscillation, El Niño Southern Oscillation and beyond. Proceedings of the Royal Society of London B-Biological Sciences 270, 2087-2096.

Stervander, M., Lindström, Å., Jonzén, N. \& Andersson, A. (2005). Timing of spring migration in birds: Long-term trends, North Atlantic Oscillation and the significance of different migration routes. Fournal of Avian Biology 36, 210-221.

Stöckli, R. \& Vidale, P. L. (2004). European plant phenology and climate as seen in a 20-year AVHRR land-surface parameter dataset. International foumal of Remote Sensing 25, 3303-3330.

Stralberg, D., Jongsomjit, D., Howell, C. A., Snyder, M. A., AlexanDER, J. D., WIENS, J. A. \& Root, T. L. (2009). Re-shuffling of species with climate disruption: a no-analog future for California birds? PLoS ONE 4, e6825.

Strandberg, R. \& Alerstam, T. (2007). The strategy of fly-and-forage migration, illustrated for the osprey (Pandion haliaetus). Behavioral Ecology and Sociobiology 61, 1865-1875.

Strode, P. K. (2003). Implications of climate change for North American wood warblers (Parulidae). Global Change Biology 9, 1137-1144.

Studds, G. E. \& Marra, P. P. (2005). Non-breeding habitat occupancy and population processes: An upgrade experiment with a migratory bird. Ecology 86, 2380-2385.

Studds, G. E. \& MARra, P. P. (2007). Linking fluctuations in rainfall to nonbreeding season performance in a long-distance migratory bird, Setophaga ruticilla. Climate Research 35, 115-122.

Sutherland, W.J. (1998). Evidence for flexibility and constraint in migration systems. Fournal of Avian Biology 29, 441-446.

SzÉP, T. (1995). Relationship between West African rainfall and the survival of the Central European adult Sand Martin Riparia riparia population. Ibis 137, $162-168$.

Szép, T., Møller, A. P., Piper, S., Nuttall, R., Szabo, Z. D. \& Pap, P. L. (2006). Searching for potential wintering and migration areas of a Danish barn swallow population in South Africa by correlating NDVI with survival estimates. Fournal of Ornithology 147, 245-253.

Teplitsky, C., Millls, J. A., Alho, J. S., Yarrall, J. W. \& Merilä, J. (2008). Bergmann's rule and climate change revisited: Disentangling environmental and genetic responses in a wild bird population. Proceedings of the National Academy of Sciences, USA 36, 13492-13496.

Thackeray, S. J., Sparks, T. H., Frederiksen, M., Burthe, S., Bacon, P.J., Bell, J. R., Botham, M. S., Brereton, T. M., Bright, P. W., Carvalho, L. Clutton-Brock, T., Dawson, A., Edwards, M., Elliott, J. M., HarRington, R., Johns, D., Jones, I. D., Jones, J. T., Leech, D. I., Roy, D. B., Scott, W. A., Smith, M., Smithers, R. J., Winfield, I. J. \& Wanless, S. (2010). Trophic level asynchrony in rates of phenological change for marine, freshwater and terrestrial environments. Global Change Biology 16, 3304-3313.

Thaxter, C. B., Joys, A. C., Gregory, R. D., Baillie, S. R. \& Noble, D. G. (2010). Hypotheses to explain patterns of population change among breeding bird species in England. Biological Conservation 143, 2006-2019.

Thomas, C. D., Cameron, A., Green, R. E., Bakkenes, M., Beaumont, L. J., Collingham, Y. C., Erasmus, B. F. N., de Siqueira, M. F., Grainger, A., Hannah, L., Hughes, L., Huntley, B., van Jaarsveld, A. S., Midgley, G. F., Miles, L., Ortega-Huerta, M. A., Peterson, A. T., Phillips, O. L. \& Williams, S. E. (2004). Extinction risk from climate change. Nature 427, 145-148.

Thomas, C. D. \& Lennon, J. J. (1999). Birds extend their ranges northwards. Nature 399, 213-213.

Thorup, K., Alerstam, T., Hake, M. \& KJellén, N. (2006). Traveling or stopping of migrating birds in relation to wind: An illustration for the osprey. Behavioral Ecology 17, 497-502.

Thorup, K., Bisson, I. A., Bowlin, M. S., Holland, R. A., Wingfield, J. C., RAMENOFSKY, M. \& Wikelski, M. (2007). Evidence for a navigational map stretching across the continental US in a migratory songbird. Proceedings of the National Academy of Sciences, USA 104, 18115-18119.
Tøttrup, A. P., Rainio, K., Coppack, T., Lehikoinen, E., Rahbek, C. \& Thorup, K. (2010). Local temperature fine-tunes the timing of spring migration in birds. Integrative and Comparative Biology 50, 293-304.

Tøttrup, A. P., Thorup, K., Rainio, K., Yosef, R., Lehikoinen, E. \& Rahbek, C. (2008). Avian migrants adjust migration in response to environmental conditions en route. Biology Letters 4, 685-688.

Tylianakis, J. M., Didham, R. K., Bascompte, J. \& Wardle, D. A. (2008). Global change and species interactions in terrestrial ecosystems. Ecology Letters 11, $1351-1363$.

Vähätalo, A. V., Rainio, K., Lehikoinen, A. \& Lehikoinen, E. (2004). Spring arrival of birds depends on the North Atlantic Oscillation. Fournal of Avian Biology $35,210-216$.

Valiela, I. \& Martinetto, P. (2007). Changes in bird abundance in eastern North America: Urban sprawl and global footprint? Bioscience 57, 360-370.

Van Buskirk, J., Mulvihill, R. S. \& Leberman, R. C. (2010). Declining body sizes in North American birds associated with climate change. Oikos 119, 1047-1055.

van der Graf, S. A. J., Stahl, J., Klimkowska, A., Bakker, J. P. \& Drent, R. H. (2006). Surfing on a green wave - how plant growth drives spring migration in the Barnacle Goose Branta leucopsis. Ardea 94, 567-577.

van Noordwijk, A. J., Pulido, F., Helm, B., Coppack, T., Delingat, J., Dingle, H., Hedenström, A., van der Jeugd, H., Marchetti, C., Nilsson, A. \& Pérez-Tris, J. (2006). A framework for the study of genetic variation in migratory behaviour. Fournal of Ornithology 147, 221-233.

Van Turnhout, G. A. M., Foppen, R. P. B., Leuven, R. S. E. W., Van Strien, A. \& SiePEL, H. (2010). Life-history and ecological correlates of population change in Dutch breeding birds. Biological Conservation 143, 173-181.

Végvári, Z., Bókony, V., Barta, Z. \& Kovács, G. (2009). Life history predicts advancement of avian spring migration in response to climate change. Global Change Biology 16, 1-11.

VEPSÄLÄINEN, K. (1968). The effect of the cold spring 1966 upon the Lapwing Vanellus vanellus in Finland. Ornis Fennica 45, 33-47.

Visser, M. E. \& Bотн, C. (2005). Shifts in phenology due to global climate change: The need for a yardstick. Proceedings of the Royal Society of London, Series B: Biological Sciences 272, 2561-2569.

Visser, M. E., Both, C. \& Lambrechts, M. M. (2004). Global climate change leads to mistimed avian reproduction. Advances in Ecological Research 35, 89-110.

Visser, M. E., Caro, S. P., van Oers, K., Schaper, S. V. \& Helm, B. (2010). Phenology, seasonal timing and circannual rhythms: towards a unified framework. Philosophical Transactions of the Royal Society of London, Series B: Biological Sciences 365, 3113-3127.

Visser, M. E., Holleman, L. J. M. \& Caro, S. P. (2009a). Temperature has a causal effect on avian timing of reproduction. Proceedings of the Royal Society of London, Series B: Biological Sciences 276, 2323-2331.

Visser, M. E., Holleman, L. J. M. \& Gienapp, P. (2006). Shifts in caterpillar biomass phenology due to climate change and its impact on the breeding biology of an insectivorous bird. Oecologia 147, 164-172.

Visser, M. E., Perdeck, A. C., van Balen, J. H. \& Both, C. (2009b). Climate change leads to decreasing bird migration distances. Global Change Biology 15, $1859-1865$.

VISSER, M. E. \& SANZ, J. J. (2009). Solar activity affects avian timing of reproduction. Biology Letters 5, 739-742.

Walther, G. R., Post, E., Convey, P., Menzel, A., Parmesan, C., Beebee, T. J. C., Fromentin, J. M., Högh-Guldberg, O. \& Bairlein, F. (2002). Ecological responses to recent climate change. Nature 416, 389-395.

Webster, M. S. \& Marra, P. P. (2005). The importance of understanding migratory connectivity. In Birds of two worlds: The ecology and evolution of migration (eds. R. GreenberG \& P. P. Marra), pp. 199-209. Johns Hopkins University Press, Baltimore, Maryland, U.S.A.

Wiens, J. A., Stralberg, D., Jongsomjit, D., Howell, G. A. \& Snyder, M. A. (2009). Niches, models, and climate change: Assessing the assumptions and uncertainties. Proceedings of the National Academy of Sciences, USA 106, 19729-19736.

Wilson, W. H., Jr. (2009). Variability of arrival dates of Maine migratory breeding birds: Implications for detecting climate change. Northeastern Naturalist 16, 443-454.

WingField, J. C. (2008). Organization of vertebrate annual cycles: Implications for control mechanisms. Philosophical Transactions of the Royal Society of London, Series B: Biological Sciences 363, 425-441.

Zalakevicius, M., Bartkeviciene, G., Raudonikis, L. \& Janulaitis, J. (2006). Spring arrival response to climate change in birds: A case study from Eastern Europe. Fournal of Ormithology 147, 326-343.

Zuckerberg, B., Woods, A. M. \& Porter, W. F. (2009). Poleward shifts in breeding bird distributions in New York State. Global Change Biology 15, 1866-1883. 


\section{SUPPORTING INFORMATION}

Additional supporting information may be found in the online version of this article.

Appendix S1. Patterns of differential migration.

Appendix S2. Important concepts in the study of bird migration and climate change.

Appendix S3. Theory for studying bird migration and

climate change.

(Received 28 August 2010; revised 24 March 2011; accepted 27 March 2011; published online 13 April 2011)
Appendix S4. Correlation-based measures of concordance.

Please note: Wiley-Blackwell are not responsible for the content or functionality of any supporting materials supplied by the authors. Any queries (other than missing material) should be directed to the corresponding author for the article. 